\title{
Neutral Taxation of Shareholder Income? Corporate Responses to an Announced Dividend Tax
}

\author{
ANNETTE ALSTADSÆTER \\ ERIK FJÆRLI
}

\section{CESIFO WORKING PAPER No. 2530 \\ CATEgORY 1: Public FinANCE}

JANUARY 2009

\footnotetext{
An electronic version of the paper may be downloaded

- from the SSRN website: Www.SSRN.com

- from the RePEc website: Www.RePEc.org

- from the CESifo website: www.CESifo-group.org/wp
} 


\title{
Neutral Taxation of Shareholder Income? Corporate Responses to an Announced Dividend Tax
}

\begin{abstract}
The introduction of the 2006 Norwegian shareholder income tax was announced in advance, and it increased top marginal tax rates on individual dividend income from zero to 28 percent. We document strong timing effects on dividend payout on a large panel of non-listed corporations, with a surge of dividends prior to 2006 and a sharp drop after. Mature firms are more likely to pay dividends, and high asset growth increases the probability of retaining all earnings. Intertemporal income shifting through the timing of dividends seems to be a drain on internal equity and cause increases in the corporations' debt-equity ratios. The debt ratios drop sharply after the implementation of the reform.
\end{abstract}

JEL Code: G32, G35, H24, H25.

Keywords: neutral dividend tax, dual income tax, intertemporal income shifting, anticipation effects, corporate financial policy, transition.

\author{
Annette Alstadsceter \\ Institute of Health Management and Health \\ Economics \\ University of Oslo \\ P.b. 1089 Blindern \\ 0317 Oslo \\ Norway \\ annette.alstadsater@medisin.uio.no
}

\author{
Erik Fjærli \\ Research Department \\ Statistics Norway \\ P.O. Box 8131 Dep. \\ 0033 Oslo \\ Norway \\ erik.fjarli@ssb.no
}

January 10, 2009

We have benefited from comments by Erling Holmøy, Vesa Kanniainen, Jukka Pirttilä, Arvid Raknerud, Hans Henrik Scheel, Joel Slemrod, Peter Birch Sørensen, and in particular, two anonymous referees. A special thank to Michael Riis Jacobsen for inspiring discussions on the neutrality of the shareholder income tax. We also thank seminar participants at Skatteforum 2008, IIPF-conference 2008 in Maastrich, Zeuthen Workshop on Public Economics in Copenhagen 2008, and Statistics Norway for useful comments. Financial support from the Research Council of Norway and Academy of Finland is gratefully acknowledged. 


\section{Introduction}

The dual income tax is characterized by a progressive tax on earned income and a proportional tax on capital income. This tax system was first implemented in the Nordic countries nearly 20 years ago, and countries around the world have since then implemented elements of a dual income tax. ${ }^{4}$ The dual income tax is neutral in its treatment of different sorts of capital income. In its pure form, it also avoids double taxation of dividends, as dividend receipts are tax-exempt through an imputation system. The major challenge lies with the taxation of small businesses. For medium and high income classes, there is a large difference in the marginal tax rates on capital and labour income, providing great incentives for business owners to participate in tax minimizing income shifting in order to re-classify labour income as capital income, as emphasized by Sørensen (1994), Hagen and Sørensen (1998), Lindthe et.al (2004), and Alstadsæter (2007).

The prevention of such income shifting was a major motivation behind the Norwegian 2006 tax reform, which introduced a partial double taxation of dividends paid to individual domestic shareholders. Only the equity premium is subject to taxation under this new system. The normal return to the share, the so-called Rate-of-Return-Allowance, is tax exempt. We show in a simple setting with no uncertainty that in steady state, the shareholder income tax is neutral with respect to timing of dividends and capital structure of the firm. Sørensen (2005a) also shows that the shareholder income tax is neutral with respect to investment decisions and risk taking, as long as there is full loss offset.

So, with neutrality under both the new and old tax systems, the tax reform should have no other effect than on the timing of dividend payments. ${ }^{5}$ As the reform was announced in advance and a number of transitionary rules were implemented from 2004 and onward, corporations were expected to advance the distribution of profits prior to the implementation of the new tax rates. Following the hierarchy of Slemrod (1995), this is intertemporal income shifting, the least severe of agents' behavioral responses to taxation, and should not have any significant effects except transitory disturbances on the financial policy of the corporations. ${ }^{6}$ But, as stated by Korinek and Stiglitz (2008), intertemporal income shifting affects the cash

\footnotetext{
${ }^{4}$ For more on the dual tax system, see Sørensen (1994, 1998, 2005b), Nielsen and Sørensen (1997), and Boadway (2004).

${ }^{5}$ We would also expect some minor effects of the ratio of wage to dividends in the compensation of owners' labour effort in small firms where the owner also is actively involved in the day-to-day operations. An owner-manager's choice between wages and dividends is analyzed by Fjærli and Lund (2001).

${ }^{6}$ See also Gordon and Slemrod (2000) for a broad discussion of different types of income shifting.
} 
balance of the corporation and might thus have negative effects on investments in the following periods.

In this paper we examine a panel of 75.433 Norwegian non-listed corporations' dividend policy based on their annual accounting statements for the accounting years 19992006. In addition, we have information on their type of owners, ownership shares, and owners' received dividends. We also analyze which impact excessive dividend payments prior to the 2006 tax reform had on the corporations' financial structure. We have three main results. First, we find strong timing effect on dividend payments, both around the temporary dividend tax in 2001 and around the announced and permanent shareholder income tax in 2006. Aggregate proposed dividends in our sample increased by 82 percent the last year before the introduction of the shareholder income tax, and dropped by 41 percent after the reform. In particular, there are strong responses on the extensive margin, which are the same results found by Chetty and Saez (2005). But this timing effect is substantially smaller in firms where the owners transferred their shares to holding companies prior to 2006, as dividends paid to corporations are tax exempt under the shareholder income tax. Second, we find support for the life-cycle view of the corporation, as argued by Sinn (1991). In our sample, mature firms are more likely to pay dividends. High asset growth in a corporation increases the probability of retaining all earnings. These effects are even stronger when considering the probability of paying excessive dividends (proposed dividends are higher than profits). The very significant impact of growth on the propensity to retain all earnings indicates that internal funding can be of special importance for growing firms. Tax motivated dividend distributions could therefore have an additional cost through reduced cash holdings and thus reduced investment opportunities in the future, as argued by Korinek and Stiglitz (2008). Third, we find that intertemporal shifting of income through the timing of dividends drains the corporations for internal equity and increases their debt-equity ratios. This effect is more pronounced in the smaller corporations with concentrated ownership. ${ }^{7}$

A partial double taxation of dividend income was introduced also in Finland in 2005, as an addition to their dual income tax system. The anticipation effects of this reform are analyzed in Kari, Karikallio and Pirttilä (2008). They document an increased dividend payout prior to the reform by firms that most likely would be affected by the new dividend tax. It seems like this increase in dividend payments did not come at the expense of new 
investments, but rather was financed partially by new debt. The effects of the dual income tax on related issues as taxable income, demand for debt, tax progressivity, and choice of business organizational form, are studied by Aarbu and Thoresen (2001), Fjærli (2004), Thoresen (2004), Thoresen and Alstadsæter (2008), and Alstadsæter and Wangen (2008) on Norwegian data. Similar studies are conducted on Swedish data by Selén (2002) and Hansson (2004), and on Finnish data by Kari (1999) and Pirttilä and Selin (2006).

Different theories on the corporation's motivation for distributing dividends, as well as the effects of taxes, are presented in section 2 in this paper. The previous and present taxation of the Norwegian corporate sector are described in section 3, where also the neutrality of the shareholder tax is discussed. Section 4 presents the data, and in section 5 we present the empirical findings. Section 6 concludes.

\section{Theories on the effects of taxes on corporations' financial policy}

Different views on the motives behind the corporation's dividend payments lead to different conclusions regarding the effect of taxes on the corporations' financial policy. According to the familiar early results of Modigliani and Miller (1958) and Miller and Modigliani (1961), dividend policy and the source of finance are irrelevant for share value in efficient markets. But market imperfections, such as agency costs and taxes introduce distortions.

Under the agency problem of free cash flow hypothesis of Jensen (1986), firms increase dividend payments when they anticipate declining investment opportunities in the future. It is a way to control managers from investing in less profitable internal projects and waste cash in more mature firms with limited growth possibilities.

Lintner (1956) found in a survey that managers only increase dividends when they are sure to be able to maintain future dividend payments of this level. This is the starting point of the signaling view on dividend payments, where dividends can signal private information on profitability. Firms are reluctant to cut dividend payments, as this is perceived as a negating signal of rentability to the market. A large literature finds evidence that stock prices increase for corporations that announce dividend increases and fall when corporations announce

\footnotetext{
${ }^{7}$ This paper focuses on possible indirect tax reform effects on investments through income shifting and consequences for cash balance. Anticipated tax reforms can also affect investments directly, as emphasized by Alvarez et al. (1998).
} 
dividend cuts. ${ }^{8}$ Bernheim and Wantz (1995) argue that taxes make dividends more expensive as a signal. Thus the signal of profitability inherent in dividend payments is stronger in the presence of taxes.

More recent views on dividend payments are the clientele view, where investors prefer dividend paying stocks from behavioral explanations (see Allen and Michaely, 2003, for an overview), and the catering view, where managers pay dividends when dividend-paying stocks are in demand, and not when it is the other way round (Baker and Wurgler, 2004).

Under the so called old view (or corporate finance view) on dividend taxation, new share issues is the marginal source of funds. Dividend taxes in combination with corporate taxes impose a double taxation of dividend income and makes debt more attractive as a source of finance. Dividend taxes distort the investment decision of the firm and might prevent free allocation of capital in the economy, as argued by Harberger $(1962,1966)$. The corporate tax discriminates against investments in the corporate sector and allocates capital towards the non-corporate sector, implying a welfare loss through an inefficient resource allocation. It can also prevent the founding of new firms.

In contrast, under the new view (or trapped equity view) on dividend taxation developed by King (1974), Auerbach (1979), Bradford (1981), double taxation of dividends does not necessarily distort the firm's investment decision. Retained earnings are the marginal source of finance and dividends are paid with the residual cash flow. Repurchasing of shares is not possible. The dividend tax is neutral regarding the marginal investment decision in steady state but it imposes a proportional reduction in the marked value of equity. The dividend tax can thus be distortionary when it comes to raising new equity capital. An announced dividend tax cut has no effect on dividend payments, given that is perceived as permanent. But if the tax cut is perceived as temporary, this will spur intertemporal income shifting through the timing of dividends. ${ }^{9}$

The nucleous view (Sinn, 1991) builds on a life-cycle view of the firm with three phases; start-up, growth, and maturity. The dividend tax reduces initial investments in a startup-firm and slows down the growth rate, thus prolonging the middle phase in the life-cycle of the firm (where only retained earnings are used for financing expansion), and postponing the mature, dividend-paying phase. Dividend taxation is neutral when the firm is mature, in line with the new view, but creates distortions in growth firms, in line with the old view.

\footnotetext{
${ }^{8}$ See Allen and Michaely (2003) for an overview.

${ }^{9}$ See Auerbach (2003) for an overview on the different views on the effect of dividend taxation on corporate policy.
} 
Korinek and Stiglitz (2008) build on the life-cycle view of Sinn (1991) and also allow the firms to transfer financial assets between periods. Growth firms are assumed to be capital constrained and reliant on some level of cash holdings. They find that unanticipated dividend tax change has only small effects on aggregate investments, as investments are financed through retained earnings in growing firms that do not pay dividends. An announced tax change will on the other hand induce firms to participate in intertemporal income shifting through the timing of dividend payments. This will affect the firm's cash holdings and in turn its investment level. They argue that even short-term timing effects can have long term real effects on the economy through the effect on the cash holding in credit constrained firms. Similarly, Gordon and Dietz (2009) and Chetty and Saez (2007) develop agency costs based models for the effect of dividend taxation on firm's investments and financial policy. Gordon and Dietz (2009) evaluate three different theories on dividend behavior, the new view, a signaling model and an agency model. They conclude that the agency model corresponds better to stylized facts on firms and dividend behavior.

There is a large, but inconclusive, empirical literature analyzing the effects of dividend tax on the firms' financial policy. Poterba and Summers (1985) find support for the old view on UK data, as do Hines (1996) and Poterba (2004) on US data. Bond, Devereux and Klemm (2007) find support for the new view on recent UK data. Auerbach and Hasset (2002) and Desai and Goolsbee (2004) find some support for the new view on U.S. data. Chetty and Saez (2005) conduct an early analysis of the 2003 US dividend tax cut, and find a large timing effect of dividend payments among the listed corporations that constituted their data sample. The rapid increase in dividend payments was stronger among firms with high levels of accumulated assets and firms with strong owners. As they argue in Chetty and Saez (2007), this is more in line with an agency cost model of dividend behavior. Auerbach and Hasset (2006, 2007) document that the 2003 U.S. dividend tax cut affected equity markets and firm valuation, with a positive effect on firm value of dividend paying firms.

There also seems to be an overall trend that fewer firms are paying dividends. Fama and French (2001) find that there is a substantial decline in the proportion of US listed firms that pay dividends. DeAngelo et al. (2004) also find evidence that the reduction in dividends is primarily driven by fewer firms paying dividends. This is due to a changing composition of corporations, and that dividend payments are concentrated among the largest, most profitable listed US corporations. Some support for this is found by Denis and Osobov (2008) on international data. 


\section{The Norwegian dual income tax system}

The Norwegian version of the dual income tax involves a flat, basic tax rate that applies to both corporate income, and to capital and labour income at the personal level. The basic tax rate that applies to all income has been fixed at 28 percent in the whole period after the introduction of this scheme in 1992. In addition, labour income is taxed by a progressive surtax, which implies that top marginal tax rates for wage incomes are substantially higher than the marginal tax rate on capital income. When including the employers' social security contributions of 14.1 percent on wage payments, total top marginal tax rates on wage income were 59 percent, 65.5 percent, and 58 percent in the years 1992, 2001, and 2005, respectively. ${ }^{10}$

\subsection{Taxing income from the corporate sector 1992-2005}

Dividends were tax exempt 1992-2005. ${ }^{11}$ The exception is 2001, when a dividend tax of 11 percent applied to all dividend receipts above a threshold. Capital gains were taxed at 28 percent. The so-called RISK-model prevented double taxation of realized capital gains that originated in withheld profits. When taxable capital gains on realized shares were computed, a deduction was allowed for accumulated retained profits in the corporation, as these were already taxed at 28 percent at the corporate level. Andersson et al. (1998) discuss this in more detail.

There were strong incentives to shift income from the labour income tax base to the capital income tax base. The split model of dual income taxation was designed to prevent this income shifting, and it applied to sole proprietors and corporations with more than $2 / 3$ of shares held by active owners. ${ }^{12}$ Under the split model, a return to the labour effort of the active owner is imputed, and this is taxed as labour income independently of whether it is actually paid as wages, dividends, or retained in the firm. First, the imputed return to capital is calculated, at an annually determined imputation rate (this has varied between 10 and 16

\footnotetext{
${ }^{10}$ These employers' social security contributions actually vary geographically between 0 and 14.1 percent, and are lower for employees living further away from urban centers. In this paper we only consider the normal rate of 14.1 in calculations. As these contributions are deductible labour costs when taxable profits on corporate level are calculated, they only account for additional $14.1 * 0.72=10.15$ percentage points to total marginal tax on wage income.

${ }^{11}$ In principle, dividends were taxable at the capital income tax rate, 28 percent. But a full imputation system allowed deduction for taxes paid at the corporate level. As the corporate tax rate is also 28 percent, this meant that in practice there was no taxation of dividend income.

12 An owner is characterized as active if he works more than 300 hours annually in the firm. Spouses or under-aged children of active owners are not recognized as passive owners. Originally, also children of age could not be considered passive
} 
percentage points) times total assets in the firm. A deduction for the human capital contribution to profits is calculated as 20 percent of total wage costs, with some restrictions. Imputed return to labour is then taxable profits net of both the imputed return to capital and the human capital deduction and taxable imputed return to labour are assigned to the active owners according to their ownership shares in the firm. If imputed return to labour is negative, it is forwarded for deduction against future positive imputed return to labour in the same corporation. The split model and the incentives for income shifting are described and analyzed by Hagen and Sørensen (1998), Lindhe et al. (2004), Alstadsæter (2007), Alstadsæter and Wangen (2008) and Thoresen and Alstadsæter (2008). At the same time as the difference between the top marginal tax rates on labour and capital increased during the 1990ies increased, it also became easier to legally participate in income shifting between the tax bases through more lenient regulations within the split model.

As shown in figure 1, there was a substantial increase in dividend income among households from 1993 to 2005 . Also, one can see clear timing effects as responses to the dividend taxes of 2001 and 2006. There was a period of strong economic growth throughout the 1990ies, and this accounts for part of the increased dividend payments throughout the period. Also, the lowering of marginal tax rates on capital income spurred savings in the household sector. To the extent that these savings were channeled into the corporate sector, this can explain some of the increase in dividends. But a lot of this dividend growth can also be attributed to changing economic incentives for the firms through the introduction of the dual income tax in $1992^{13}$, as discussed by Alstadsæter, Fjærli and Thoresen (2006). The dramatic reduction of top marginal tax rates on capital income through this reform made retained earnings relatively more expensive as a source of finance compared to debt than before the 1992 tax reform. Also, the incentives to re-label labour income of the owners as dividend income probably contributed strongly to this trend of increased dividend receipts by the households.

owners. After only a couple of years that changed, enabling a tax free intergenerational transfer from parents to adult children through dividend payments to aged children as passive owners in the family firm.

${ }^{13}$ A remission of postponed taxes that released large funds in the corporations also contributed to the increase in dividends. 
Figure 1. Received dividends by households in Billion NOK, 1993-2007.

Source: Statistics Norway.

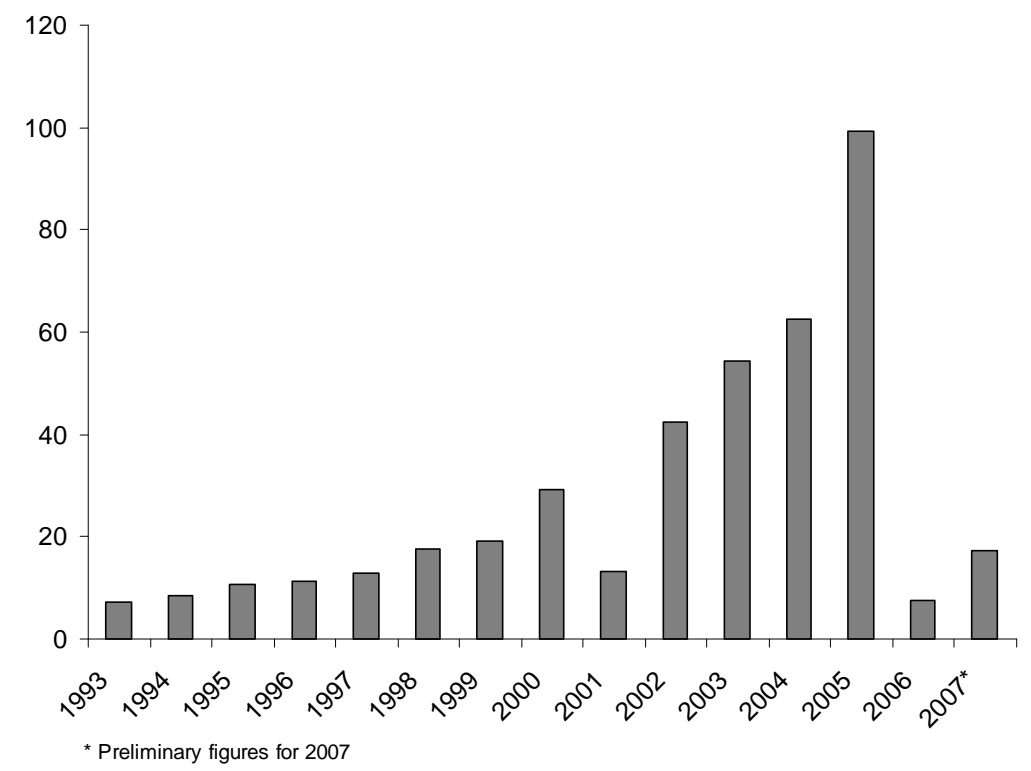

\subsection{Taxing income from the corporate sector from 2006 and onward - The shareholder income tax}

The first warning of a tax increase in prospect came in June 2000, when the parliament approved a temporary tax on capital gains and dividends for the income year 2001, "to be replaced by a new tax system in 2002". In 2001, the interim tax was abolished, but no new tax system was introduced. Instead, an expert committee was appointed early 2002. The Skauge Committee presented its recommendations early 2003, the government proposal came early 2004, and transitory rules were passed on March 26, 2004. The parliament agreed to the reform the same year, to be implemented from January 1, 2006.

The shareholder income tax ensures equal tax treatment of all personal owners of corporations, independent of ownership composition. Only the equity premium is subject to taxation under this new system. The risk-free return to the share, the so-called Rate-of-ReturnAllowance, is tax exempt. The shareholder income tax applies to all income from shares, both dividends and capital gains. This means that the effective marginal tax rate on income from shares is 48.2 percent, close to the top marginal tax rate on labour income of 47.8 percent. ${ }^{14}$

The Rate-of-Return-Allowance (RRA) is the imputed risk-free return to the share, which is defined as the product of the imputation rate and the stepped-up basis of the share. 
The stepped-up basis of the share is the sum of its acquisition price (for shares purchased before 2006, special regulations apply for the imputation of this price) and all previous unused RRA's. The imputation rate is set at the end of each year as an average of the after-tax interest rate on bonds during the year, and was 2.1 percent for 2006 and 3.3 percent for 2007.

Dividends that exceed the RRA are taxable at the capital income tax rate. If received dividends are less than the RRA, the remaining is added to the imputation basis of the share for the calculation of future RRAs. In addition, the unused RRA for this year is forwarded and added to the imputed RRA the following year. The share specific RRA can not be transferred between different types of shares and only the person who owns the share at yearend will benefit from the calculated RRA for that year. At realization, the taxable capital gain from the share is the capital gain net of accumulated unused RRAs. Any remaining unused RRAs cannot be carried forward and cannot be deducted against other income. Only actual capital losses at realization are tax deductible (not losses that stems from unused RRAs). ${ }^{15}$

The shareholder income tax only applies to Norwegian resident individuals. Dividends paid to corporations are tax exempt, as are corporations' capital gains from realization of shares. This latter rule is the so-called Exception-model, and was implemented without warning on March 26, 2004, prior to the shareholder income tax.

A transition rule ensured that if an individual shareholder sold his shares in a corporation to another corporation during 2005, and was compensated in the form of shares in this new corporation, no capital gains taxes applied. This was the so-called transition rule E, and the motivation for this was to equalize tax treatment of personal shareholders and individuals who owned shares through a holding company. Now all individual shareholders had the possibility to transfer their shares to a holding company without triggering any capital gains tax under the pre-reform regime. The shareholder income tax only applies when dividends or capital gains are realized by individuals.

\subsection{The neutrality of dividend and capital gains taxation}

In a simple setting where we disregard uncertainty, we will now show that both under the preand post-reform dual income tax systems, the after-tax income of an individual investor is

\footnotetext{
${ }^{14}$ For the income year 2006.
} 
independent of whether profits are distributed or retained in the corporation, then generating a realizable capital gain. Also, neither of the tax systems should affect the timing of dividends or the corporations' choice between debt and equity. First we describe the former system based on imputation credits and then the present shareholder income tax based on rate of return allowances. ${ }^{16}$

\subsubsection{The dual income tax with full imputation.}

We do not include the split model in this set-up, as the imputed taxable labour income under the split model is calculated based on gross profit and the value of real assets, and is independent of whether net profits are paid as dividends or retained. Apart from the value of assets in place, the value, $V$, of a corporation immediately before the ex-dividend date is assumed to be the sum of the current period's dividend payments, $D$, and after tax profits retained in the firm, $\pi(1-\tau)-D$, where $\pi$ is gross profits, and $\tau$ is the corporate tax rate. Assume that one additional unit of retained earnings increases the value of the share, and thus also realizable capital gains, $G$, by one unit. When denoting the individual's tax payments on dividends and capital gains by $T_{D}$ and $T_{G}$, respectively, the value of the corporation can be expressed as

$$
V=\left[D-T_{D}\right]+\left[G-T_{G}\right]=\left[D-T_{D}\right]+\left[(1-\tau) \cdot \pi-D-T_{G}\right]
$$

The individual's tax payments on dividends and capital gains were both based on a full imputation system, as described in the previous section. The imputation rate for taxable dividends, $i_{D}$, is given by $i_{D}=\tau /(1-\tau)$, and the nominal imputation amount for capital gains (deductions in capital gains for the retained after-tax profits under the RISK-model), $I_{G}$, is given by $I_{G}=(1-\tau) \cdot \pi-D$. Actually, the deduction $\mathrm{I}_{\mathrm{G}}$ includes all accumulated retained earnings in the past, but in this simple setting $\mathrm{I}_{\mathrm{G}}$ is simply equal to the current period's retentions. Both dividend income and capital gains are taxed according to the capital income tax rate, $t_{k}$, which is identical to the corporate tax rate. Total tax payments on dividends and capital gains are then given by

$$
T_{D}=t_{k} \cdot\left(D+i_{D} \cdot D\right)-i_{D} \cdot D=\left[t_{k}-\frac{1-t_{k}}{1-\tau} \cdot \tau\right] \cdot D \stackrel{t_{k}=\tau}{\rightarrow} T_{D}=0
$$

and

\footnotetext{
${ }^{15}$ The mechanisms in the shareholder income tax are illustrated in Sørensen (2005a), Jacobsen (2008), and Alstadsæter, Fjærli and Thoresen (2006).
} 


$$
T_{G}=t_{k} \cdot\left[(1-\tau) \cdot \pi-D-I_{G}\right]=t_{k} \cdot[(1-\tau) \cdot \pi-D-((1-\tau) \cdot \pi-D)]=0 .
$$

The imputation system for dividend taxation is based on the presumption that dividends paid should not be related to income that is not yet taxed according to the tax rules for income accrual. Thus, if dividends paid one year exceed after tax profits, a correction income of $\pi_{c}=D-(1-\tau) \cdot \pi$ is added to taxable corporate profits that year. The correction income is carried forward and deducted against future taxable profits in the corporation, provided that after tax profits minus dividends in the future is greater than or equal to the correction income carried forward. Thus, the correction income represents only an intertemporal shift in tax payments for the corporation with no permanent effect on the total tax liability of the firm. Note that the correction tax is remitted by the corporation, and not by the individual. When dividends paid exceed after tax book profits, the $\mathrm{I}_{\mathrm{G}}$ is not reduced as there will be an "income" of $\pi_{c}=D-(1-\tau) \cdot \pi$ added to taxable profits. As we shall show below in section 3.3.3, this special arrangement created a loophole in the transition from the imputation system to the new system.

The full imputation of taxes paid by the corporation and the tax credit for retained earnings ensure that tax payments on received dividends, $\mathrm{T}_{\mathrm{D}}$, and capital gains, $\mathrm{T}_{\mathrm{G}}$, are both zero for the individual, except in special circumstances, such as windfall gains or when dividends are received from foreign companies. Also, the corporate tax rate equals the individual tax rate on interest income and interest expenses. Consequently, the after-tax return on savings is the same in the corporate sector and in the household sector, and the dividend decision is independent of taxes.

With no double taxation of dividends and no tax on capital gains from retained profits, the total tax rate on equity is the same as the tax rate on interest income, and equal for all types of investors. Thus, under full certainty, there will be no tax-favouring of different sources of funds and the tax system does neither affect the corporations' choice of debt versus equity nor the investors' portfolio choice. ${ }^{17}$

Finally, let us consider the investment decision. The real interest rate $r$ represents the investors' pre-tax required rate of return, and the pre-tax marginal rate of return corporate

\footnotetext{
${ }^{16}$ The neutrality of the dual income tax and the shareholder income tax are also analyzed by Sørensen $(1998,2005)$, and by Nielsen and Sørensen (1997) on the trade-off between human and non-human capital.

${ }^{17}$ The capital gains tax will reduce the equity premium, but will also reduce the after-tax risk under uncertainty.
} 
investments is represented by F'. In the presence of taxes, the investment condition is given by

$$
F^{\prime}=\frac{\left(1-t_{k}\right)}{(1-\tau)} \cdot r \quad \stackrel{\substack{t_{k}=\tau \\ \rightarrow}}{\rightarrow} F^{\prime}=r
$$

As the corporate tax rate equals the individual tax rate on capital income, we see from (4) that the investment condition reduces to $F^{\prime}=r$, which means that the individual's investment decision is independent of taxes under the dual income tax with full imputation.

\subsubsection{The shareholder income tax.}

The tax rate on individual capital income and capital gains, $t_{k}$, is still equal to the corporate tax rate, $\tau$, as under the full imputation system. Allowances in both taxable gains and taxable dividends are made for the alternative return to the investment, and the RRA is defined as $r^{*} \cdot K$, where $r^{*}$ is the imputation rate and $K$ is the stepped-up basis of the share. Dividend payments are not taxable for the individual until they exceed the RRA. Total tax on shareholder income is given by $T$ :

$$
T=T_{D}+T_{G}=t_{k} \cdot\left[D-r^{*} \cdot K+\pi \cdot(1-\tau)-D\right]=t_{k} \cdot\left[\pi \cdot(1-\tau)-r^{*} \cdot K\right] .
$$

Similar to the imputation system, the shareholder model too is based on the presumption that the dividends paid are already taxed at the hand of the corporation. Thus, the correction tax is continued after the tax reform. However, the correction tax has the same implications under the two systems and is relevant only for the working of the special transitional regulations that will be explained in section 3.3.3.

As we see from equation (5), tax on shareholder income is independent of whether profits are distributed to owners as dividends or retained in the corporation and generating a realizable capital gain.

The shareholder income tax is also neutral regarding the timing of dividends, as we clearly see by considering this in a simple two-period setting. Assume that first period profits are not paid in full as dividends, and dividend payments are less than the RRA, such that $D_{1}<r^{*} \cdot K$. The remaining profits, $\pi_{1}-D_{1}>0$, are saved in the firm at the real interest rate, $r$, until the next period and then paid out together with the earned after-tax interest. For simplicity, assume that no profit is generated in the second period. No shareholder income tax 
applies in period 1, and the individual can carry forward the unused RRA with interest, and this is given by $\left(r^{*} \cdot K-D_{1}\right) \cdot\left(1+r^{*}\right)$. This unused RRA is then deducted from taxable dividends (or capital gains) next year, since the unused RRA is added to the second period stepped-up basis of the share, and to total RRA in the second period as well. Total income, $Y$, of the individual after two periods is then given by

$$
\begin{aligned}
Y & =\left[1+\left(1-t_{k}\right) \cdot r\right] \cdot D_{1} \\
& +[1+(1-\tau) \cdot r] \cdot\left(\pi_{1}-D_{1}\right) \\
& -t_{k} \cdot\left\{[1+(1-\tau) \cdot r] \cdot\left(\pi_{1}-D_{1}\right)-r^{*} \cdot K-\left(1+r^{*}\right) \cdot\left(r^{*} \cdot K-D_{1}\right)\right\}
\end{aligned}
$$

The first line of (6) is the second period value of dividends paid in the first period. The second line represents first period retained earnings that have generated after-tax interest income in the firm and that are distributed as dividends in the second period. The third line represents the individual's total tax payments on received dividends in the two periods. No dividend taxes apply in the first period, as dividends are less that the RRA. The first part of line three of (6) is dividend tax payments in period 2 if all dividends were subject to the dividend tax. But the accumulated rate-of-return allowance is tax exempt, and total second period RRA is represented by the tax credit in the second part of the expression in the third line. As is seen from equation (7) below, the individual's total income is independent of the timing of dividend payments, $d Y / d D_{1}=0$, as long as the imputation rate is the after-tax interest rate and the corporate tax rate equals the capital income tax rate, $(1-\tau) \cdot r=r^{*}$ and $\tau=t_{k}$ :

$$
\begin{aligned}
\frac{d Y}{d D_{1}} & =\left[1+\left(1-t_{k}\right) \cdot r\right]-\left(1-t_{k}\right) \cdot[1+(1-\tau) \cdot r]-t_{k} \cdot\left(1+r^{*}\right) \\
& =t_{k}[1+(1-\tau) \cdot r]-t_{k}\left(1+r^{*}\right)
\end{aligned}
$$

So, the net value of the stream of dividends is independent of the timing of dividends under the shareholder income tax. Since only the returns in excess of the after tax interest rate is subject to the tax, the investor will also be indifferent between holding debt and holding equity, from a pure tax point of view.

As shown by Sørensen (2005a), the shareholder income tax is neutral with respect to investment decisions and risk taking, as long as there is full loss offset. He also shows that the RRA in combination with the stepped-up basis of the share ensures neutrality with respect to financing by new equity versus debt. 


\subsubsection{The transition from the imputation system to the RRA system and incentives for intertemporal income shifting}

Contrary to the steady state financing decisions under each of the two tax systems, the transition from the imputation based system to the new system based on RRA implies temporary tax incentives for shifting income between the two periods. Since the average tax rate in the individual investor's dividend income after the 2006 tax reform approaches the marginal rate of about 48 percent while the average and marginal tax rates before the reform was 28 percent, stock-owners would wish to have as much as possible of their planned dividends taxed before the tax increase came into effect. This is particularly true if the indivudals expected a further increase in the tax on shareholder income in the future, such as the introduction of a general dividend tax through the removal of the RRA.

In order to better understand the incentives to shift income between periods, we will now compare total taxes on profits distributed as dividends on corporate and personal level before and after the reform and we explain two sources of tax arbitrage. These are arbitrage by changes in the cash holdings of corporations and arbitrage by changes in the debt ratios. Also, we will explain one particular loophole related to the transition regulations. To simplify, we disregard the active owner's choice between paying wages or dividends and assume that the owner-manager initially is rewarded by dividends. We thus assume that all profits, $\pi$, are distributed as dividends.

\section{Tax arbitrage by changes in the optimal level of cash balances of capital constrained firms}

This type of arbitrage is explained by Korinek and Stiglitz (2008), where changes in the firms' optimal level of cash on hand leads to temporary increases or reductions in the stream of dividends out of the corporate sector. Their model is based on the assumption that owners discount cash holdings within firms at a higher rate than cash holdings outside the firms because of agency concerns. Another assumption is that it is costly or difficult for corporations to instantaneously raise new external capital, for example due to asymmetric information between firms and outside investors and lending institutions. ${ }^{18}$ Consequently, corporations will have to rely on working capital to finance investments and the optimal level of cash holdings is determined by a trade off between the value of cash on the hand of the firm, represented by the future after-tax profits from random investment opportunities, and the value of cash on the hand of the shareholders. The latter depends on the current average tax 
on dividend receipts, while the former depends on the future tax rates. As long as the dividend tax rates are constant, the optimal cash holding is in steady state and independent of the tax rate on dividends. However, if dividend tax rates are expected to increase in the near future, firms will reduce the level of cash balances in order to have dividends taxed at the current low tax rates rather than after the tax increase. This will also reduce the firms' investments prior to the tax increase. Thus, the major effect of the tax arbitrage is that funds are shifted out of the corporate sector and one would expect to observe a negative correlation between dividend payments and corporations' growth rates after the announcement of a tax increase ${ }^{19}$.

\section{Tax arbitrage by borrowing}

Being based on asymmetric information between insiders (management) and outsiders, the Korinek- Stiglitz approach is more relevant for the behavior of large, widely held corporations that rely on the capital market and are subject to these capital market imperfections and agency problems. However, in many firms there will be a "private line" between the management and a dominant owner or an owner group that resolves the agency problems. A substantial part of the corporate sector consists of closely held corporations where the owner(s) and the management are one and the same. In a closely held corporation, dividends can be taken out of the firm at the low tax rate and then immediately reinvested as new equity that can be repaid to the owners at a later point in time (repayment of original equity is normally tax exempt).

In this section we focus on intertemporal income shifting in an owner-managed firm through borrowing. Assume that the shareholder maximises the present value of after-tax dividends in period 1, which is the last period of the old tax system with no tax on dividends, plus period 2, which is the first period of the new tax system with a tax on dividends above the RRA. Also assume that the shareholder normally would receive dividends $D_{2}>r^{*} \cdot K$ after the tax reform, named period 2. This means that the shareholder expect to have a positive taxable dividend income in period 2 , in other words $\mathrm{D}_{2}$ can be interpreted as dividends that exceeds the RRA in period 2. Denote the personal tax rate on interest income and on dividends after the tax reform by $t_{k}$ and the corporate tax rate by $\tau$, as in equation (5) above. Before the tax reform, in period 1 , the maximum dividend that can be paid out is

\footnotetext{
${ }^{18}$ Myers and Majluf (1984).

${ }^{19}$ For further details of the model, we refer the reader to Korinek and Stiglitz (2008).
} 


$$
D_{1}=M_{1}+B_{1}-\tau \cdot \max \left\{0,\left[D_{1}-(1-\tau) \cdot \pi\right]\right\}=M_{1}+B_{1}-T_{\pi c}
$$

In expression (8), $\mathrm{M}_{1}$ denotes cash on hand after investments are made in period 1 and includes this period's after tax profits, $\mathrm{B}_{1}$ denotes additional debt beyond the investment needs in period 1 and $\mathrm{T}_{\pi \mathrm{c}}$ denotes the temporary tax on correction income. As explained above, $\mathrm{T}_{\pi \mathrm{c}}$ is positive if dividends are paid out of income that is not yet taxed by the taxdefined rules for income accrual, and it will be reversed in the future (period 2) when dividend payments are reduced sufficiently below after-tax profits. In period 2 , the loan $\mathrm{B}_{1}$ plus interest expenses are repaid by retained profits and the correction tax is negative. The maximum net dividend in excess of the RRA is

$$
\begin{aligned}
& D_{2}=\left[(1-\tau) \cdot\left(\pi_{2}-r \cdot B_{1}\right)-B_{1}+T_{\pi c}\right] \cdot\left(1-t_{k}\right) \\
& =\left\{\pi_{2} \cdot(1-\tau)-\left[1+(1-\tau) \cdot r \cdot B_{1}\right]\right\} \cdot\left(1-t_{k}\right)+T_{\pi c} \cdot\left(1-t_{k}\right)
\end{aligned}
$$

Given a total budget constraint of $\mathrm{M}_{1}+\pi_{2}(1-\tau)$, the period 1 present value of maximum total dividends in the two periods is

$$
D=D_{1}+\beta \cdot D_{2},
$$

where $\beta$ is the discount factor $\left[1+\left(1-t_{k}\right) r\right]^{-1}$. Provided that all additional borrowing in period 1 is used to finance additional dividends (for a given level of investments), the effect on $\mathrm{D}$ from borrowing is given by

$$
\frac{\partial D}{\partial B}=1-\beta \cdot[1+(1-\tau) \cdot r] \cdot\left(1-t_{k}\right)-\left[1-\beta \cdot\left(1-t_{k}\right)\right] \cdot \tau_{\pi c}
$$

In (11), the tax rate $\tau_{\pi \mathrm{c}}$ takes the value $\tau$ if the dividend payment in period 1 triggers correction tax, zero otherwise. The intuition of (11) is that one additional unit of dividends paid in period 1 reduces gross dividends in period 2 by one plus the after-tax interest expenses. Due to the dividend tax, net dividends in period 2 is only reduced by $\left(1-t_{k}\right)$ times the gross dividends. In addition, there will eventually be a cost related to the negative tax credit associated with a possible correction tax. The after-tax value of this cost is increased by the discount factor $\beta$ and by the dividend tax (provided that the correction tax refund in period 2 is paid out to the owners). 
Since $t_{k}=\tau,(11)$ reduces to

$$
\frac{\partial D}{\partial B}=t_{k}-\left[1-\beta \cdot\left(1-t_{k}\right)\right] \cdot \tau_{\pi c}>0
$$

Initially, the owners can save the entire dividend tax of $t_{k}$ by shifting income from period 2 to period 1 by borrowing. This implies that investments are financed by debt rather than equity. However, increasing period 1 dividends beyond period 1 taxable income can lead to a correction tax that is refunded later, in period 2. The correction tax refund increases the tax base for period 2 dividend taxation when paid out. So, for the owners the net after tax value of the correction tax is higher than the after-tax value of the correction tax refund. On the other hand, taxation of interest income reduces the after-tax discount rate and increases the present value of the refund. The expression (12) is always positive even when there is a correction tax, and the tax arbitrage should continue to the $\mathrm{D}_{2}$ equals the RRA, or to a point where it will be prevented by non-tax legal regulations or capital market constraints.

\section{Tax arbitrage by utilizing legal loopholes}

The main purpose of the tax reform was to stop income shifting between the labour and capital income tax bases without worsening the conditions for investment and economic growth. Thus, the corporate sector was given generous transition rules, such as the opportunity to organize investment activities in tax-exempt holding companies. Another transition rule allowed the tax-payers to add the imputation amount $\mathrm{I}_{\mathrm{G}}$ for capital gains (see the discussion of equations (2) and (3) above) to the starting value for the base for calculation of the RRA. Increasing dividends before the tax reform reduces $I_{\mathrm{G}}$ proportionally and this transition rule was intended to make it unnecessary for corporations and owners to withdraw previously earned and taxed equity from the from the corporations just to insert it again the next day as new equity and as such a part of the RRA calculation base. Instead, the earned equity, represented by the imputation amount $\mathrm{I}_{\mathrm{G}}$, could be put directly into the base for calculation of RRA. However, due to the interaction with the correction tax arrangement, a special loophole emerged as the full details of the shareholder income tax were revealed for the tax planners during 2004. The loophole works as follows: 
As explained above, when dividends exceed taxable profits, the corporation is assigned a correction income of $\pi_{c}=D-(1-\tau) \cdot \pi$. The calculated correction income is considered taxable income, so the capital gains imputation amount changes by the amount $\Delta I_{G}=(1-\tau) \cdot \pi-D+D-(1-\tau) \cdot \pi=0$. So, beyond the point $D=(1-\tau) \cdot \pi$, further dividend payments will not reduce the $\mathrm{I}_{\mathrm{G}}$ and the base for the calculation of RRA. However, when inserted back into the firm, the additional dividends will increase the starting value for the RRA-base and in this way, the previously earned equity is used twice to increase the base for the $\mathrm{RRA}^{20}$. Similar to the borrowing arbitrage in (12) above, there will be a present-value cost from this operation related to the correction tax, but the net gain from this transaction is still positive.

\subsubsection{Summary of income shifting incentives}

While the cash balance effect predicts a negative impact of the tax reform announcement on growth, the incentives inherent in (12) should lead to an increase in the debt ratios of firms from the announcement of the tax reform to its implementation. Afterwards, both dividends and debt should decline. Due to the loophole related to the interaction of correction income, imputation credit and the transition rule, one should expect to se a particularly strong increase in the occurrences of dividends in excess of taxable profits in 2004, which is the final accounting year before the tax reform, and an increase in new equity rather than new debt in the accounting year 2005 due to reinvestment of dividends.

The anticipation of an increase in future tax rates on dividend income thus involve several types of incentives that could lead to different sorts of accommodation. First, dividends should increase from 2001 to 2005, and one should see frequent payments of dividends in excess of after tax profits. Debt ratios should also increase from the accounting years 2001 to 2004. Second, one should see particularly frequent occurrences of dividends beyond profits in 2004, followed by an increase in new equity in 2005. Third, dividends and debt ratios should drop from 2005 and onwards, and internal (earned) equity should correspondingly increase sharply. Finally one should see a negative correlation between dividend payments and asset growth, due to the Korinek - Stiglitz effect. However, such a

\footnotetext{
${ }^{20}$ According to a official statement from the tax authorities, the dividends did not need to be actually paid out, only set aside and then converted to new equity. Thus no liquidity was needed as long as the firm could render probable that it was solid enough that it could have borrowed the funds needed.
} 
negative correlation could also be explained by the view that growing corporations generally prefer retained earnings.

\section{Empirical analysis}

In this section we examine the dividend policy of the firms prior to the tax reform and just after its implementation, and the implications of dividend policy for financial structure. Two key subjects are addressed: First, we look at effects on dividend policy: Did the announcement of a coming tax reform around 2001-2002 lead to intertemporal income shifting among corporations mainly owned by households? How did these firms respond to the announcement of the 2006-reform and later to the implementation of this reform? Second, we examine how responses in dividend policy affected firms' financial structure. Did excess dividend payments by income shifters cause changes in firms' debt ratios or were foregone internal equity replaced by new equity injections? Are there indications that excess dividend payments may have come at the expense of growth, i.e. that valuable investment opportunities may not have been undertaken, as suggested by Korinek and Stiglitz (2008)?

Chetty and Saez (2005) point out that mean dividends to a large extent are driven by few top tax payers, which could make statistical inference about the dividend policy difficult from a small sample. They therefore look upon initiations and terminations of dividend payments on the extensive margin, and on changes in dividends paid by dividend paying firms on the intensive margin. With our data that covers more than half of the corporate sector, this is not a major problem. In our analysis we look at initiations, terminations and dividend changes as in Chetty and Saez (2005), but we also analyze dividends in terms of zero vs. positive payments and the frequency of dividends in excess of net after-tax profits.

If excess payments were high prior to the reform and/or there are alternative ways to distribute such as repayment of the original capital or loans given by shareholders, the transition period may take some more time and dividends would grow only slowly the first years after the reform. Our data does not cover a sufficiently long period to tell how dividend policy will be like after the reform.

Regarding the question whether excess dividend payment increases the propensity to become capital constrained or not, this needs to be examined by an analysis of the investment behaviour in corporations over a sufficiently long period. This is beyond the scope of the present paper. What we examine here is whether distributed profits are replaced by new 
equity or by debt, and whether there is a negative correlation between excess dividend payments and asset growth. Of course, such a negative correlation does not prove that dividends come at the expense of growth, but would give an indication of the importance of retained earnings as a source of funds for growing firms. The importance of retained earnings and sufficient financial slack is a necessary condition for capital constraints to be a possible obstacle for investments. No negative correlation between dividends and growth would indicate that firms can easily finance growth by external funds (debt or new share issues).

As discussed earlier, there are two simultaneous income shifting incentives inherent in the announced dividend tax. First, the incentive to shift income between periods and to pay extraordinary dividends in the years prior of 2006. Second, the reduced incentive to shift income between tax bases with the introduction of the shareholder income tax, that is, from the labour income tax base to the capital income tax base. The first effect is the focus of this paper. We do not have information on owner's wage payments to themselves. But, we would expect owners to pay more wages after 2006. This since the difference in the marginal tax rates in labour and capital income decreases, and also since there is an additional pension motive for receiving wage payments, as documented by Fjærli and Lund (2001).

\subsection{Data}

The empirical documentation is based on two major data sources. The Accounting Register contains figures from the profit and loss statement and the balance sheet, and proposed dividends for the period 1999-2006. The Shareholder Register links corporations with each domestic owner (corporate or individual) and contains information of ownership (identification number and number of shares) and dividends paid. In principle, both data sources cover the entire population of corporations and owners. However, the Shareholder Register is relatively new, being established in 2004, and the first year is not complete.

It is important to be aware of the differing definitions in these two data sources. In the Accounting Register, all figures refer to the accounting year. Dividends for year $t$ are proposed dividends, payable in year $t+1$. This can deviate substantially from dividends actually paid in year $t+1$, which are proposed dividends in year $t$ plus extraordinary dividends in year $t+1$. In the Shareholder Register, all figures refer to the income year. That means that dividends in year $t$ are actual total received dividends in year $t$. Thus, dividends paid and reported in the Shareholder Register in 2006 must be compared to the proposed dividends of 
the Accounting Register in 2005, and these two figures will not be identical. Dividends received by households as displayed in figure 1 corresponds to total dividends paid from the Shareholder register.

As documented by Thoresen and Alstadsæter (2008) and Alstadsæter and Wangen (2008), the pre-2006 dual income tax spurred tax-minimizing income shifting through the choice of organizational form. To avoid noise in the data due to entry and exit of firms, we rely on balanced panel data. This means that we only include firms that are present in the Accounting Register in the whole period of 1999-2006.

As discussed in section 2, there are several theories on the motives for corporation's dividend payments. Corporations are explicitly or implicitly assumed to be large and publicly traded, with many shareholders. Norwegian corporations listed on the stock exchange are to a large extent owned by institutions or the Government, as documented by Baker et al. (2006), while there is a much larger share of individual owners in non-listed corporations. This is clearly seen from table 1 . In 2004, households received only 6.6 percent of total dividend payments from listed corporations, while the corresponding number was 45 percent for nonlisted corporations. The shareholder income tax of 2006 only applies to dividend payments to individuals, and should thus have a greater impact on dividend payments in non-listed corporations. Another factor is the income shifting aspect between different types of compensation; in smaller corporation with concentrated ownership and no clear separation between ownership and management, one would expect tax favored dividends to be used to compensate the owner-manger's labour effort instead of wages prior to 2006. The introduction of the shareholder income tax makes such re-labeling of income more expensive, and we expect both that these owner-managers accelerate dividend payments prior to 2006, and that they pay less dividends as a substitution for wages after the reform. In addition, Baker et al. (2006) find that taxes seem to play a minor role in the dividend decision of managers of Norwegian listed corporations. All these factors mean that we expect to see less pronounced timing responses of dividend payments to the announced 2006 shareholder income tax in larger, listed corporations. And as is clearly shown in table 1, the majority of timing responses to the shareholder income tax seem to come in the non-listed sector and especially in dividend payments to households. We thus exclude publicly traded corporations from the sample.

In order to identify non-listed corporations with concentrated ownership, we rely on information from the Shareholder Register in 2004. We thus also exclude firms not present there. This leaves us with a panel of 75,433 corporations that spans 8 years, 1999-2006. This 
constitutes 59 percent of total corporations in 1999, and 52 percent of total corporations in 2005. 51 percent of the corporations in our sample had concentrated ownership in 2004, defined as being fully owned by less than 5 personal owners. This means that we have a panel of fairly mature firms at the introduction of the dividend tax in 2006.

Table 1: Total, nominal dividends received, by share marketplace, shareholder sector and year. Million NOK. Source: Statistics Norway, Shareholder register.

\begin{tabular}{|c|c|c|c|c|}
\hline & 2004 & 2005 & 2006 & 2007 \\
\hline \multicolumn{5}{|c|}{ From listed corporations } \\
\hline All sectors & 28275 & 36019 & 44734 & 53750 \\
\hline $\begin{array}{l}\text { General } \\
\text { government }\end{array}$ & 9889 & 14826 & 20327 & 22444 \\
\hline $\begin{array}{l}\text { Financial } \\
\text { corporations }\end{array}$ & 4286 & 3938 & 4194 & 4324 \\
\hline $\begin{array}{l}\text { Non-financial } \\
\text { corporations }\end{array}$ & 4957 & 4261 & 4179 & 8193 \\
\hline Households* & 1869 & 2488 & 1899 & 2170 \\
\hline Rest of the world & 7025 & 9909 & 13843 & 16082 \\
\hline \multicolumn{5}{|c|}{ From non-listed corporations } \\
\hline All sectors & 137140 & 221534 & 137794 & 163688 \\
\hline $\begin{array}{l}\text { General } \\
\text { government }\end{array}$ & 2741 & 3324 & 3847 & 4761 \\
\hline $\begin{array}{l}\text { Financial } \\
\text { corporations }\end{array}$ & 2355 & 3205 & 8183 & 7870 \\
\hline $\begin{array}{l}\text { Non-financial } \\
\text { corporations }\end{array}$ & 41195 & 72239 & 68164 & 91593 \\
\hline Households* & 61664 & 101001 & 4929 & 13788 \\
\hline Rest of the world & 28365 & 40704 & 52490 & 45059 \\
\hline
\end{tabular}

* Including non-profit institutions serving as households.

\subsection{Descriptive statistics}

There were strong timing effects in dividend payments prior to the introduction of the 2006 shareholder income tax, as shown in figure 1 and table 1 . We find the same effect in our panel of closely held corporations. As is seen in table 2, there is a surge in proposed dividends in 2004, payable in 2005. Proposed dividends increased by 82 percent from 2003 to 2004, with a return to the 2003-level in 2005. The increase in total dividend payments in 2005 is in fact even greater, as extraordinary dividend payments are not registered here. But at the same 
time, this was a period of strong economic expansion, and the corporations had a dramatic increase in profits, such that one might argue that a 82 percent increase in proposed dividends is not that unusual when aggregate profits increased by 116 percent. More remarkable is then the dramatic drop of 41 percent in proposed dividends in 2005, payable in 2006, when aggregate profits increased by 33 percent.

The combination of the so-called transition rule $\mathrm{E}$ (which rendered an optional capital gains tax exemption at the realization of shares to a corporation as long as the compensation is in form of shares in this other corporation), tax exemption for dividends paid to corporations as owners from March 26, 2004, and no tax on dividends until January $1^{\text {st }} 2006$ provided firms strong incentives to realize capital gains and distribute earnings as tax exempt dividends during the accounting year of 2004. This probably is some of the explanation for the extreme increase in corporate profits from 2003 to 2004.

Table 2. Selected nominal aggregate accounting figures, in Mill. NOK, for our balanced panel of non-listed and non-publicly traded corporations. 75,433 corporations.

\begin{tabular}{lcccc}
\hline Year & Net profit & $\begin{array}{c}\text { Proposed } \\
\text { dividends * }\end{array}$ & Assets & $\begin{array}{c}\text { Percentage } \\
\text { dividend payers }\end{array}$ \\
\hline $\mathbf{1 9 9 9}$ & 64402 & 41326 & 1759394 & 36 \\
$\mathbf{2 0 0 0}$ & 84707 & 38897 & 2016694 & 30 \\
$\mathbf{2 0 0 1}$ & 61855 & 59510 & 2164692 & 36 \\
$\mathbf{2 0 0 2}$ & 56698 & 68126 & 2177738 & 40 \\
$\mathbf{2 0 0 3}$ & 81052 & 75303 & 2231473 & 41 \\
$\mathbf{2 0 0 4}$ & 175005 & 137400 & 2352270 & 48 \\
$\mathbf{2 0 0 5}$ & 233351 & 81591 & 2573134 & 9 \\
$\mathbf{2 0 0 6}$ & 272091 & 86711 & 2792568 & 19 \\
\hline
\end{tabular}

*Remember that total dividends paid in year $t$ are proposed dividends in year $t-1$ plus extraordinary dividend payments in year $t$.

Source: Statistics Norway, Accounting Register.

The above factors also have contributed to a changing ownership structure.

Considering the total of Norwegian corporations, the number of corporations that were fully directly owned by households decreased by 18 percent from 2004 to 2006. In 2004, the personal ownership share of total number of shares was 71 percent for all corporations, while this had decrease to 59 percent in 2006. More interestingly, personal owners held 87 percent of the shares in corporations that paid dividends to households in 2004. Personal ownership had decreased to 45 percent for these same corporations in 2006. 
The reduction in dividends after the implementation of the reform is expected and can be explained by two factors. One is the pure timing effect, as the corporations accelerate their dividend payments prior to the reform. This is only a transitory effect. The other reason is that closely held corporations either find substitutes for dividend payments such as hiding consumption expenditures into the operating expenses of their firm or that they believe that tax rates will drop again in the future. In the meanwhile, the corporation is used more or less as a savings box. This is a more permanent effect.

Dividends do not disappear completely. Dividend payments to foreigners and to corporations are tax exempt, such that one would expect an increase in the use of holding companies and dividend payments to corporations, as also is seen in table 1 . But as seen in table 2, these dividend payments are concentrated among few firms after the reform. Only 9 and 19 percent of the corporations in our panel had proposed dividends payable in 2006 and 2007 , respectively, while 48 percent of the corporations had proposed dividends payable in 2005.

Table A.4 in the appendix shows the number and fraction of dividend paying firms that increase their dividends by more (less) than 20 percent from the previous year, for the entire sample and for closely held corporations. It appears that given the decision to pay dividends in two subsequent periods, the nominal distributions change according to the tax motives both in 2000 and in 2004-2005. Among the closely held corporations, almost 50 percent increased the dividend payments by more than 20 percent in 2004, and about 67 percent reduced dividends in 2005. However, the most prominent effect of the 2006 tax reform is obviously a strong reduction in the fraction of firms paying dividends, as is demonstrated in tables A.1 and A.2. The fractions of dividend paying closely held corporations decreased strongly in 2000 and 2005. Between 2000 and 2004, the percentage of firms paying excess dividends increased from 6 to 31 among closely held corporations, with close to zero firms proposing to pay excess dividends payable in 2006. There is also a steady increase in dividend paying corporations during the period, with a sudden drop in corporations proposing dividends in 2005, payable in 2006. As much as 52 percent of closely held corporations terminated the proposing of dividends in 2005.

As indicated by table 3 below, there is a clear tendency for debt-asset ratios to increase in the years prior to the reform in small corporations and in closely held corporations. In the accounting year 2004, when dividends payments peaked, the debt-asset ratios peaked too, indicating that internal equity to a large extent were replaced by debt. After the sharp 
drop in dividend payments from the accounting year 2005, we see a rapid decline in the debtasset ratios in smaller and closely held corporations.

Table 3. Debt-asset ratios 2000 - 2006. Corporations ranked descending by total assets.

\begin{tabular}{lcccc}
\hline Year & All corporations & 5th decile & 10th decile & $\begin{array}{c}\text { Closely held } \\
\text { corporations }\end{array}$ \\
\hline 2000 & 0.58 & 0.74 & 0.57 & 0.58 \\
2001 & 0.59 & 0.76 & 0.58 & 0.61 \\
2002 & 0.59 & 0.80 & 0.57 & 0.65 \\
2003 & 0.57 & 0.79 & 0.54 & 0.67 \\
2004 & 0.64 & 0.83 & 0.62 & 0.71 \\
2005 & 0.61 & 0.73 & 0.60 & 0.59 \\
2006 & 0.60 & 0.69 & 0.59 & 0.54 \\
\hline
\end{tabular}

\subsection{Dividend policy: Extensive margin}

Our empirical set up is based on the theoretical models by Sinn (1991) and Korinek and Stiglitz (2008), where firms start with an initial issue of shares and then grow entirely by internal funds in the first stage. No dividends are paid until the final stage, when each firm reaches its steady state path. Taxes enter the dividend decision through the intertemporal income shifting motive, as discussed in section 3.4.

We are mainly concerned with firms owned by individuals, and in particular closely held firms. In this setting, closely held firms are defined as being fully owned by 5 or less owners. We suppose that owner-managers are impatient in the sense that they discount their dividend income with a subjective discount factor which is smaller than the market discount factor. Typically, this occurs when individuals expect their income to grow, but face credit constraints that limit their opportunity to borrow against their future income prospects. ${ }^{21} \mathrm{On}$ the other hand, capital constrained firms with limited access to the capital market may be forced to keep some financial slack in the firm, in order to be able to undertake valuable investment opportunities. Both the existence of imperfect capital markets and the financially constrained owner's demand for dividend payments imply that firms are capital constrained in equilibrium.

\footnotetext{
${ }^{21}$ In widely held firms, low discount factors for future dividends are explained by agency theories: Shareholders are afraid that selfish managers will spoil the means on bad projects if they are allowed to keep too much of the profits within the firm.
} 


\section{Empirical model}

Define $V_{R}$ as the increments to the owners' value function from the alternative retain all profits, and $V_{D}$ as the value added from the alternative to pay the dividend $\mathrm{D}^{22}$. D may possibly come at the expense of real investments or force the firm to increase the share of costly external financing.

Following MacKie-Mason (1990), we define the relative incremental value of retention rather than payout, $\mathrm{V}$, by

$$
\mathrm{V}=\mathrm{V}_{\mathrm{R}}-\mathrm{V}_{\mathrm{D}}=\mathrm{x}^{\prime} \beta_{\mathrm{R}}+\xi_{\mathrm{R}}-\mathrm{x}^{\prime} \beta_{\mathrm{D}}+\xi_{\mathrm{D}}=\mathrm{x}^{\prime} \beta+\xi, \quad \xi \sim \mathrm{N}\left(0, \sigma^{2}\right)
$$

$V_{R}$ and $V_{D}$ are not observable, but we observe the corporation's choice given by $Y_{i t}=1$ if the firm $i$ in period $t$ retain all of its profits and $\mathrm{Y}_{\mathrm{it}}=0$ otherwise. The probit model to be estimated then rests on the assumption that $\operatorname{pr}(\mathrm{Y}=1)=\operatorname{pr}(\mathrm{V}>0)^{23}$, or

$$
\operatorname{pr}\left(\mathrm{Y}_{\mathrm{it}}=1 \mid \mathrm{x}_{\mathrm{it}}\right)=\operatorname{pr}\left(\xi<\mathrm{x}^{\prime} \beta\right)
$$

The estimates of the parameters are obtained by maximum likelihood. The $\mathrm{x}$ 's are listed in table 4 below.

\begin{tabular}{|c|c|c|}
\hline Variable & Expected sign & Explanation \\
\hline Grow & + & Dummy, Growth phase, defined as book value 2006/Book value $1999>2$ \\
\hline Mature & - & Dummy, "Phase 2". Mature firm defined as age $>10$ years \\
\hline Neg & + & Dummy, negative equity. Legal constraints on dividend payments \\
\hline $\mathrm{d} 00$ & + & $\begin{array}{l}\text { Time dummy, Dividends are taxable this accounting year (the following } \\
\text { income year) }\end{array}$ \\
\hline $\mathrm{d} 01$ & - & Time dummy, Temporary dividend tax abolished this accounting year \\
\hline $\mathrm{d} 02$ & - & $\begin{array}{l}\text { Time dummy, Skauge committee appointed (tax reform announcement } \\
\text { effect) }\end{array}$ \\
\hline $\mathrm{d} 03$ & - & Time dummy, tax reform announcement effect continues \\
\hline $\mathrm{d} 04$ & - & $\begin{array}{l}\text { Time dummy, tax reform announcement effect continues +last chance to } \\
\text { pay tax exempt dividends }\end{array}$ \\
\hline $\mathrm{d} 05$ & + & $\begin{array}{l}\text { Time dummy, dividends taxable this accounting year (the following } \\
\text { income year }\end{array}$ \\
\hline $\mathrm{d} 05 \mathrm{O}$ & - & $\begin{array}{l}\text { Time dummy year }=2005 \text { multiplied by dummy for change in ownership } \\
\left.\text { from personal to corporate (the transitional rule } \mathrm{E})^{*}\right)\end{array}$ \\
\hline $\mathrm{d} 06$ & + & Dividends taxable \\
\hline $\mathrm{d} 06 \mathrm{O}$ & - & $\begin{array}{l}\text { Dummy year }=2006 \text { multiplied by dummy change in ownership from } \\
\text { personal to corporate (the transitional rule E) }\end{array}$ \\
\hline
\end{tabular}

Table 4. Regressors and their expected impact on the decision to retain all earnings

\footnotetext{
$\left.{ }^{*}\right)$ The reference category for ownership is firms that initially are owned by individuals in 2004 and remain owned by individuals. In the regressions on the entire sample, which also include corporations that are owned by other corporations, we also add a dummy for firms that remain owned by corporations (before and after the reform), d05C and d06C.

${ }^{22}$ Besides being an important assumption in the corporation life cycle set-up in Sinn (1991), it is an empirical fact that the dividend decision often involves a discrete choice, as is evident also in our Norwegian data. The amount paid as dividends is considered exogenous in this stylized model, and will in general depend on profits, investment opportunities and the cost of external financing.

${ }^{23}$ This is identical to the revealed preference restriction in MacKie-Mason (1990).
} 
The model is estimated using different representations of Y:

1. Dividends paid vs. not paid.

2. Excess dividends paid vs. not paid. Excess dividends are defined as dividends $>$ book profits.

3. Dividend initiation (from zero to positive dividends).

4. Dividend termination (from positive to zero).

In the first two specifications, the reference year is 1999 , while the reference year is 2000 in specification 3 and 4. Separate regressions are performed on the total sample and on closely held firms. A corporation is defined as closely held if it is 100 percent owned by 5 or less individuals in the year 2004 .

\section{Results}

We concentrate the following discussion of the results of the probit regressions on closely held corporations ${ }^{24}$, because this group seems to show the strongest response to timing incentives of the announced dividend tax. These results are reported in table 5 below. Similar results are obtained (and reported in table A.4 in the appendix) for all corporations in our panel.

Table 5. Results of probit analysis. Closely held corporations, Number of observations $=302956$.

\begin{tabular}{|c|c|c|c|c|c|c|c|c|}
\hline & \multicolumn{2}{|c|}{ 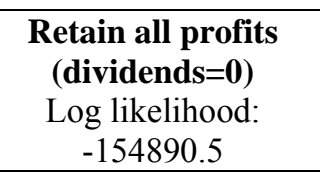 } & \multicolumn{2}{|c|}{$\begin{array}{c}\text { Excess dividends=0 } \\
\text { Log likelihood: } \\
-104600.8 \\
\end{array}$} & \multicolumn{2}{|c|}{$\begin{array}{c}\text { Initiation=1 } \\
\text { Log likelihood: } \\
-80565.9 \\
\end{array}$} & \multicolumn{2}{|c|}{$\begin{array}{c}\text { Termination=1 } \\
\text { Log likelihood: } \\
-86181.1 \\
\end{array}$} \\
\hline & Estimate & $\begin{array}{r}\text { Std. } \\
\text { Error }\end{array}$ & Estimate & $\begin{array}{r}\text { Std. } \\
\text { Error }\end{array}$ & Estimate & $\begin{array}{r}\text { Std. } \\
\text { Error }\end{array}$ & Estimate & Std.error \\
\hline Intercept & 0.126 & 0.007 & 1.138 & 0.009 & -1.787 & 0.010 & -1.428 & 0.008 \\
\hline Grow & 0.164 & 0.007 & 0.231 & 0.009 & 0.082 & 0.009 & -0.069 & 0.009 \\
\hline Mature & -0.201 & 0.006 & -0.179 & 0.007 & -0.011 & 0.007 & 0.104 & 0.007 \\
\hline Neg & 3.50 & 0.093 & 3.28 & 0.222 & -2.447 & 0.109 & -0.857 & 0.015 \\
\hline $\mathrm{d} 00$ & 0.230 & 0.010 & 0.396 & 0.014 & - & - & - & - \\
\hline $\mathrm{d} 01$ & -0.006 & 0.010 & -0.183 & 0.012 & 0.793 & 0.012 & -0.096 & 0.012 \\
\hline $\mathrm{d} 02$ & -0.148 & 0.010 & -0.498 & 0.011 & 0.707 & 0.013 & 0.007 & 0.012 \\
\hline $\mathrm{d} 03$ & -0.132 & 0.010 & -0.453 & 0.011 & 0.583 & 0.013 & 0.154 & 0.011 \\
\hline d04 & -0.357 & 0.010 & -0.697 & 0.011 & 0.821 & 0.012 & -0.060 & 0.012 \\
\hline $\mathrm{d} 05$ & 1.816 & 0.015 & 1.535 & 0.028 & -0.893 & 0.032 & 1.526 & 0.010 \\
\hline $\mathrm{d} 05 \mathrm{O}$ & -1.232 & 0.069 & -0.927 & 0.110 & 0.447 & 0.175 & -0.054 & 0.064 \\
\hline d06 & 0.960 & 0.011 & 0.683 & 0.015 & 0.730 & 0.013 & -0.910 & 0.021 \\
\hline $\mathrm{d} 06 \mathrm{O}$ & -0.765 & 0.065 & -0.359 & 0.091 & 0.277 & 0.072 & 0.822 & 0.097 \\
\hline
\end{tabular}

\footnotetext{
${ }^{24}$ Defined as closely held in the accounting year 2004.
} 
The estimated parameters reported in table 5 are highly significant and show the expected signs. Besides giving support to the view that anticipated tax changes cause intertemporal income shifting, our findings show an extremely strong response in dividend policy after the implementation of the reform. The model set-up with stylized life-cycle behaviour of firms appears to be fairly realistic, with high asset growth increasing the probability of zero dividends and with mature firms being more likely to pay dividends. The propensity to pay excess dividends shows the same pattern. Besides their self-contained significance as they give some support to the life-cycle theories of corporate financing behaviour, the growth and mature variables also serve as control variables. It is important to be aware that the observed time trend in dividend payments in a balanced panel of firms could capture both tax-motives and natural changes due to more and more firms becoming "mature" as time passes. We control for this effect by the dummy variable for maturity. The very significant impact of growth on the propensity to retain all profits indicates that retained earnings can be of special importance for the funding of growing firms. Tax motivated dividend distributions could therefore have an additional cost through capital constraints.

Second, the time-dummies show that the propensity of positive dividend payments, payment of excess dividends and dividend initiations decrease in periods with tax on dividends (accounting year 2000 and in particular 2005) and increase after the announcement of the 2006 tax reform. Terminations show the opposite pattern. Indeed, the responses in the accounting year 2005 were so strong that it gives reason to speculate whether the owners of the corporations really perceive the reform as neutral with respect to the dividend decisions. However, as we will see in the next section, repayment of original (external) equity may serve as a substitute for dividend payments, at least for some period. ${ }^{25}$

Third, in the cases where the owners have utilised the transitional rule that allowed tax-exempt transfer of shares to a tax-exempt holding company, the tax sensitivity of dividend payments, initiations and terminations becomes much lower (the $\mathrm{d} 05 \mathrm{O}$ and $\mathrm{d} 06 \mathrm{O}$ variables). When including the entire panel in the regressions, the dummy variable for being owned by a corporation during the entire period also moderate the tax sensitivity (table A.4).

Part of the reduction in dividend payments in closely held corporations after the tax reform could be due to managing owners substituting wages for dividends after the introduction of the shareholder income tax. This effect is documented by Fjærli and Lund (2001) on the Norwegian 1992 tax reform. We do not have information on this in our data. 
But as we will show in the following section, the increase in assets after the reform indicates that most reduction in dividend payments are due to increased corporate saving.

\subsection{Implications of dividend policy for capital structure}

The probit regressions reported above indicate that there is a clear negative relationship between asset growth and the propensity to pay dividends. This negative relationship is even more pronounced when we look at the propensity to pay dividends in excess of book profits. However, it is hard to tell empirically whether excessive dividend payments constrain growth or whether firms with few growth opportunities choose to pay more dividends. If leakage of working capital through dividend distributions is not replaced by new funds, there is a possibility that tax motivated excessive dividend payments could temporarily confine investments. On the other hand, if foregone internal funds are replaced by debt or equity, it is less likely that intertemporal income shifting have important real effects. The replacement of internal funds by debt vs. equity is the other issue we investigate.

From the discussion in 3.3.3 above it is clear that without the rate-of-return allowance (RRA), replacement of internal equity by external funds in the transitional phase should be in the form of low-taxed debt rather than high-taxed equity, except for the accounting year 2005. With the RRA, business owners should be indifferent between debt and equity. The details of the new tax system was not public knowledge until the government's proposal in early 2004, so if the owners just expected some kind of a tax increase on shareholder income, one should expect a decrease in internal equity and increase in the supply of debt prior to the reform, causing debt-asset ratios to rise.

Tables A.5 and A.6 in the appendix provide tests of the differences in financial structure between firms with zero dividends and firms with positive dividends. The difference-in differences estimates comes with 95 percent confidence intervals annual change in debt-asset ratios, for the entire sample and for closely held firms. Also, each of these groups is categorized by size, using book value as a control variable. For all groups and subgroups, there is a significant difference in the annual change in debt ratios for firms that pay dividends and firms that retain all profits.

In order to identify the impact on the balance from dividend payments, we perform linear regressions with OLS, using the nominal change in the different liabilities debt, internal

\footnotetext{
${ }^{25}$ More years of experience with the reform is needed to tell how it will work in the long run.
} 
(earned) equity and external (new) equity from one year to the next as dependent variables. As explanatory variables we used time dummies similar to the probit regressions (d01-d06), and time dummies multiplied with the annual change in total assets $(\Delta \mathrm{A})$. In other words, the regressions show cross section estimates of each liability's marginal share of the total change in assets plus a constant term, for each year separately. In a slightly different version we also include dummy variables for dividend payments and excess dividends payments. For example, in table 6 below, new debt accounts for around 75 percent of total change in assets in the reference period 2000 (columns 1 and 2) and new equity around 25 percent (columns $3+5$ and $4+6$ ). The results for closely held firms are reported in table 6 below. More results for all corporations sorted by asset values are reported in the appendix tables A.7 and A.8.

Table 6. Results from OLS regressions. Closely held corporations. (Number of observations

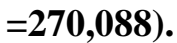

\begin{tabular}{|c|c|c|c|c|c|c|}
\hline & \multicolumn{2}{|c|}{ Change in debt } & \multicolumn{2}{|c|}{$\begin{array}{c}\text { Change in external } \\
\text { equity }\end{array}$} & \multicolumn{2}{|c|}{$\begin{array}{c}\text { Change in internal } \\
\text { equity }\end{array}$} \\
\hline & (1) & (2) & (3) & (4) & (5) & (6) \\
\hline Intercept & $-99.6^{*}$ & $-146.4^{*}$ & 22.7 & 30.0 & $84.0^{* *}$ & $124.1^{*}$ \\
\hline $\mathrm{d} 01$ & $156.8^{*}$ & $102.7^{*}$ & -19.4 & -29.1 & $-153.8^{*}$ & $-92.2^{* *}$ \\
\hline $\mathrm{d} 02$ & $283.4^{*}$ & $185.4^{*}$ & 74.8 & 56.4 & $-357.8^{*}$ & $-245.4^{*}$ \\
\hline $\mathrm{d} 03$ & $252.2^{*}$ & $158.1^{*}$ & $94.1^{* *}$ & $76.9^{* *}$ & $-348.7^{*}$ & $-241.2^{*}$ \\
\hline $\mathrm{d} 04$ & $285.5^{*}$ & $148.1^{*}$ & -71.0 & $-95.1^{* *}$ & $-135.5^{*}$ & 20.4 \\
\hline $\mathrm{d} 05$ & $-350.0^{*}$ & $-307.2^{*}$ & $170.9^{*}$ & $165.3^{*}$ & $172.0^{*}$ & $135.2^{*}$ \\
\hline $\mathrm{d} 06$ & $-187.6^{*}$ & $-167.0^{*}$ & $-79.7^{* * *}$ & $-84.6^{* * *}$ & $260.1^{*}$ & $244.5^{*}$ \\
\hline Change in assets ${ }^{a}$ & $0.75^{*}$ & $0.75^{*}$ & $0.01^{*}$ & $0.01^{*}$ & $0.23^{*}$ & $0.23^{*}$ \\
\hline $\mathrm{d} 01 \times \Delta \mathrm{A}$ & $0.03^{*}$ & $0.03^{*}$ & $0.06^{*}$ & $0.06^{*}$ & $-0.05^{*}$ & $-0.05^{*}$ \\
\hline $\mathrm{d} 02 \times \Delta \mathrm{A}$ & $-0.12^{*}$ & $-0.12^{*}$ & $0.05^{*}$ & $0.05^{*}$ & $0.05^{*}$ & $0.05^{*}$ \\
\hline $\mathrm{d} 03 \times \Delta \mathrm{A}$ & $-0.58^{*}$ & $-0.58^{*}$ & $0.03^{*}$ & $0.03^{*}$ & $0.56^{*}$ & $0.56^{*}$ \\
\hline $\mathrm{d} 04 \times \Delta \mathrm{A}$ & $-0.03^{*}$ & $-0.03^{*}$ & $0.72^{*}$ & $0.73^{*}$ & $-0.68^{*}$ & $-0.68^{*}$ \\
\hline $\mathrm{d} 05 \times \Delta \mathrm{A}$ & $-0.34^{*}$ & $-0.34^{*}$ & $0.35^{*}$ & $0.35^{*}$ & 0 & 0 \\
\hline $\mathrm{d} 06 \times \Delta \mathrm{A}$ & $-0.21^{*}$ & $-0.21^{*}$ & $-0.01^{*}$ & $-0.01^{*}$ & $0.23^{*}$ & $0.23^{*}$ \\
\hline Dividends $>0{ }^{b}$ & & $46.7^{* * *}$ & & -42.4 & & -7.6 \\
\hline Dividends $>$ profits ${ }^{b}$ & & $505.8^{*}$ & & $130.9^{*}$ & & $-612.0^{*}$ \\
\hline $\mathrm{R}^{2}$ & 0.48 & 0.48 & 0.15 & 0.15 & 0.26 & 0.26 \\
\hline $\begin{array}{l}{ }^{\mathrm{a}} \text { Change in assets }=\mathrm{DA} \\
{ }^{\mathrm{b}} \text { Dummy variable }\end{array}$ & & & $\begin{array}{l}{ }^{*} \mathrm{Si} \\
{ }^{* *} \mathrm{Si} \\
{ }^{* * *} \mathrm{Si}\end{array}$ & $\begin{array}{l}\text { int at } 1 \mathrm{pe} \\
\text { int at } 5 \mathrm{pe} \\
\text { int at } 10 \mathrm{p}\end{array}$ & $\begin{array}{l}\text { evel. } \\
\text { evel. } \\
\text { level. }\end{array}$ & \\
\hline
\end{tabular}

As seen from the dummy variables d01-d04 in tables 6, A.7 and A.8, internal equity falls significantly in the years prior to the tax reform. This is in accordance with the pattern of dividend payments reported in the probit-analyses and the frequency tables A.1 and A.2. Columns 2 and 4 illustrate the significance of excess dividend payments, as the pure time effects are reduced when the dummy variable for dividends in excess of profits is introduced. 
In the accounting year 2004, the impact on internal equity of the dummy variable for year is insignificant when we take into account excess dividends. This is in accordance with the transition rule loophole we mentioned in section 3. Based on the OLS results, it seems reasonable to conclude that dividend payments did lead to a drain of internal equity out of the corporations, according to the tax motive each year. However, the reduction in equity appears to be counteracted by a corresponding increase in debt, indicating that there may not be too much of a problem for the firms to get external funding. However, we do not know which kind of debt this is. It could thus be that part of this increased debt stems from loans from the owners, in other words, a conversion from equity to debt ${ }^{26}$. The replacement of internal equity by debt lead to a significant increase in debt ratios before the tax reform, and as shown by the appendix tables A.5 and A.6, the decision not to pay any dividends cause a significant drop in debt ratios compared to the decision to pay dividends. This holds for firms of different sizes and with different ownership structure.

After the reform, debt is reduced significantly, as seen from the D05 and D06 coefficients. This indicates that retained earnings are used to repay loans, possibly given by the owners. In 2006, external equity also declines, as repayment of original equity is used as a substitute for dividends. This appears to be particularly evident among the large corporations, as seen from table A.8. Moreover, payment of large dividends relative to profits seems to increase the external equity, indicating that the dividends received are reinvested.

\section{Conclusion}

This paper describes corporations' early responses to an announced tax reform that is based on theoretical principles that to our knowledge are new and untried in practical shareholder taxation. These principles imply in an elegant way that a more equal taxation of shareholder income and wage income is obtained without introducing investment distortions, undesirable financing incentives or adverse effects on foreign investments. Also, the tax system is compatible with Norway's international obligations through the EU and international tax agreements. Finally, it appears to be more capable of collecting tax revenue from the national corporate sector than the old split model. If successful, the shareholder income tax with RRA

\footnotetext{
${ }^{26}$ There are also other indications that a large proportion of extraordinary dividends were channelled back to the corporations as external equity or debt. New statistic from Statistics Norway based on national accounts estimates that 73 percent of dividends received by households and non-profit organizations in 2005 were reinvested in the corporate sector, either as debt or equity. Also, according to an official statement from the tax authorities allocated dividends did not need to be actually paid out, but could instead be converted directly into debt (to the owner).
} 
could be adopted by other countries too, which makes a closer investigation of the experiment interesting not only with regard to national considerations.

Our most important finding is that the timing of dividend payments appear to be very sensitive to changes in the taxation of shareholders, and that corporations with concentrated ownership have the strongest responses. In addition, extraordinarily high dividend payouts compared to after tax profits have taken place, accompanied by an increase in debt-equity ratios. This trend is especially pronounced among the relatively small and closely held firms.

The timing effect on dividend payments around the introduction of the shareholder income tax in 2006 was not only expected, but also arranged for by the government through openness and transitional rules. However, our results indicate that the heavy drop in dividend payments in 2006 possibly could involve more than just a timing effect. First, we find a sharp increase in corporate equity in the accounting year 2005. In fact, the increase in equity for the corporate sector as a whole in this single year was of the same magnitude as the entire reduction of equity from 2001 to 2004. Second, it appears from the latest official shareholder statistics that dividends continue to be low in the income year 2007, although higher than in 2006. To some extent, this could reflect that repayment of original equity replaces dividends, but the equity ratios still continue to increase.

Our results -based on a rather short time period and short experience with the new tax system- point out at least three important topics for further research and evaluation of the tax reform. First, does the sharp increase in equity ratios after the reform just reflect the timing effects and "turbulence" related to the transition or does it also involve a permanent change in the funding and payout policy? If the latter is true, what mechanisms are then at work and what will the economic consequences be? Second, if the re-allocation of dividends from individuals to holding companies and the general increase in savings on the hand of the corporations simply reflect the ultimate individual owners' need to trade stocks and rebalance their portfolios, this is intended by the legislator and represents no adverse accommodation to the reform or breach against the principles of the tax system. However, if owner-managers to a large extent use corporations as tax evasion instruments, then it would imply a lower effective shareholder income tax and a less successful reform ${ }^{27}$. Thus, a careful evaluation of the evolution of closely held corporations' accounting profits and asset composition before 
and after the reform should be of great importance. Finally, tax reforms like this create exogenous variation in the economic environment that offers an opportunity to analyze firm behavior. In the case of the 2006 tax reform in Norway, we find indications of a negative relationship between pay-out ratios and asset growth before the reform. There is a possibility that some firms may have balanced tax-motivated equity drain on one hand against the need for funds on the other hand. This invites to further research on the role of retentions as a preferred source of finance and the importance of financial slack, as originally pointed out by Myers and Majluff (1984) and recently by Korinek and Stiglitz (2008).

\section{References}

Aarbu, K. O. \& Thoresen, T. O. (2004). Income Responses to Tax Changes - Evidence from the Norwegian Tax Reform. National Tax Journal, 54(2), 319-338.

Allen, F. \& Michaely, R. (2003). Payout Policy. In Constantinides, G. M., Harris, M., \& Stulz, R. M. (eds.). Handbook of the Economics of Finance. Elsevier.

Alstadsæter, A. (2007). The Achilles heel of the dual income tax. The Norwegian case, Finnish Economic Papers, 20, 5-22.

Alstadsæter, A., Fjærli, E., \& Thoresen, T. O. (2006). Om bakgrunnen for og utformingen av skattereformen i 2006. Beta. Scandinavian Journal of Business Research, 64-80.

Alstadsæter, A. \& Wangen, K. R. (2008). Corporations' choice of tax regime when transition costs are small and income shifting potential is large. CESifo Working Paper No. 2392.

Alvarez, L. H. R., Kanniainen, V., \& Södersten, J. (1998). Tax policy uncertainty and corporate investments. A theory of tax-induced investments spurts. Journal of Public Economics, 69, 17-48.

Andersson, K., Kanniainen, V., Södersten, J., \& Sørensen, P. B. (1998). Corporate tax policy in the Nordic Countries. In. Sørensen, P. B. (eds.). Tax Policy in the Nordic Countries. London. Macmillan Press, 72-137.

Auerbach, A. (1979). Wealth maximization and the cost of capital. Quarterly Journal of Economics, 94, 433-446.

Auerbach, A. (2003). "Taxation and corporate financial policy", in Auerbach, A \& Feldstein, M. (eds). Handbook of Public Economics, Volume 3, Amsterdam. North-Holland.

\footnotetext{
${ }^{27}$ For example, tax evasion could possibly be carried out by hiding personal consumption into the corporations' operating expenses, invest corporate assets in consumption capital or transfer profit abroad.
} 
Auerbach, A. \& Hasset, K. (2002). On the marginal source of investment funds. Journal of Public Economics, 87, 205-232.

Auerbach, A. \& Hasset, K. (2006). Dividend taxes and firm valuation. New evidence. American Economic Review, 96(2), 119-123.

Auerbach, A. \& Hasset, K. (2007). The 2003 dividend tax cuts and the value of the firm. An event study. In Auerbach, A., Hines, J. R., \& Slemrod, J. (eds.). Taxing Corporate Income in the $21^{\text {st }}$ Century. Cambridge University Press.

Baker, H. K., Mukherjee, T. K., \& Paskelian, O.G. (2006). How Norwegian managers view dividend policy. Global Finance Journal, 17, 155-176.

Baker, M. \& Wurgler, J. (2004). A catering theory of dividends. Journal of Finance, 59, 1125-1165.

Bernheim, B. D. \& Wantz, A. (1995). A tax-based test of the dividend signalling hypothesis. American Economic Review, 85(3), 532-551.

Boadway, R. (2004). The dual income tax system - an overview. CESifo DICE Report, 2(3), $3-8$.

Bond, S. R., Devereux, M. P., \& Klemm, A. (2007). Dissecting dividend decisions. Some clues about the effects of dividend taxation from recent UK tax reforms. In Auerbach, A., Hines, J. R., \& Slemrod, J. (eds.). Taxing Corporate Income in the $21^{\text {st }}$ Century. Cambridge University Press.

Bradford, D. (1981). The incidence and allocation effects of a tax on corporate distributions. Journal of Public Economics, 15, 1-22.

Chetty, R. \& Saez, E. (2005). Dividend taxes and corporate behavior. Evidence from the 2003 dividend tax cut. Quarterly Journal of Economics 120(3), 791-833.

Chetty, R. \& Saez, E. (2007). An agency theory of dividend taxation. NBER Working Paper No. 13538 .

DeAngelo, H., DeAngelo, L. \& Skinner, D. J. (2004). Are dividends disappearing? Dividend concentration and the consolidation of earnings. Journal of Financial Economics, 72, 425 456.

Denis, D.J. \& Osobov, I. (2008). Why do firms pay dividends? International evidence on the determinants of dividend policy. Journal of Financial Economics, 89, 62-82.

Desai, M.A. \& Goolsbee, A. D. (2004). Investment, overhang and tax policy. Brookings Papers on Economic Activity, 2, 285-355.

Fama, E. F. \& French, K. R. (2001). Disappearing dividends. changing firm characteristics or lower propensity to pay? Journal of Financial Economics, 60, 3-43. 
Fjærli, E., \& Lund, D. (2001). The choice between owner's wages and dividends under the dual income tax, Finnish Economic Papers, 14, 104-119.

Fjærli, E. (2004). Tax reform and the demand for debt, International Tax and Public Finance $11,435-467$.

Gordon, R. H. \& Dietz, M. (2009). Dividends and taxes. In Auerbach, A. \& Shaviro, D. (eds.), Institutional Foundations of Public Finance. Economic and Legal Perspectives. Cambridge, MA. Harvard University Press.

Gordon, R. \& Slemrod, J. (2000). Are "real" responses to taxes simply income shifting between corporate and personal tax base? In. Does Atlas shrug? The economic consequences of taxing the rich. Edt. J. Slemrod. Russel Sage Foundation. Harvard University Press. Ch. 8, 240-288.

Hagen, K. P., \& Sørensen, P. B. (1998). ”Taxation of Income from Small Businesses. Taxation Principles and Tax Reforms in the Nordic Countries." In Tax Policy in the Nordic Countries. 28-71. Eds. P.B. Sørensen, P.B. London. Macmillian Press.

Hansson, A. (2004). Taxpayers Responsiveness to Tax Rate Changes and Implications for the Cost of Taxation. Department of Economics Working Paper No. 5, Lund University.

Harberger, A. (1962). The incidence of the corporation tax. Journal of Political Economy, $70(3), 215-240$.

Harberger, A. (1966). Efficiency effects of taxes on income from capital. In Krzyzakniak, M, (eds.). Effects of Corporation Income Tax. Detroit Waine State University Press.

Hines, J. R. (1996). Dividends and profits. Some unsubtle foreign influences. Journal of Finance, 51, 661-689.

Jacobsen, M. R. (2008). Norwegian Economic National Report - Taxation of capital and wage income; towards separated or more integrated personal systems. Yearbook for Nordic tax research 2008. DJØF Publishing, Copenhagen.

Jensen, M. (1986). Agency costs of free cash flow, corporate finance, and takeovers. American Economic Review, 76(2), 59-83.

Kari, S. (1999). Dynamic Behaviour of the Firm under Dual Income Taxation. VATT Research Reports 51, Government Institute for Economic Research, Helsinki

Kari, S., Karikallio, H., \& Pirttilä, J. (2008). Anticipating tax changes. Evidence from the Finnish corporate income tax reform of 2005. Fiscal Studies, 29(2), 167-196.

King, M. (1974). Taxation and the cost of capital. Review of Economic Studies, 41(1), 21-35.

Korinek A. \& Stiglitz, J. E. (2008). Dividend taxation and intertemporal tax arbitrage. NBER Working Paper No.13858. 
Lindhe, T., Södersten, J., \& Öberg, A. (2004). Economic effects of taxing different organizational forms under the Nordic dual income tax. International Tax and Public Finance, 11, 477-505.

Lintner, J. (1956). Distribution of incomes of corporations among dividends, retained earnings, and taxes. American Economic Review, 46, 97-113.

MacKie-Mason, J. K (1990). Do Taxes Affect Corporate Financing Decisions? The Journal of Finance, 45 (5), 1471-1493.

Miller, M. H. \& Modigliani, F. (1961). Dividend policy, growth, and the valuation of shares. Journal of Business, 34, 411-433.

Modigliani, F. \& Miller, H. M. (1958). The cost of capital, corporation finance, and the theory of investment. American Economic Review, 48(3), 261-297.

Myers, S. C. \& Majluf, N. S. (1984). Corporate financing and investment decisions when firms have information that investors do not have. Journal of Financial Economics, 12, 187221.

Nielsen, S. B. \& Sørensen, P. B. (1997). On the optimality of the Nordic system of dual income taxation. Journal of Public Economics, 63, 311-329.

Pirttilä, J. \& Selin, H. (2006). How successful is the dual income tax? Evidence from the Finnish tax reform of 1993, Department of Economics Working Paper No. 26, November 2006, University of Uppsala.

Poterba, J. (2004). Taxation and corporate payout policy. American Economic Review, 94(2), $171-175$.

Poterba, J. \& Summers, L. (1985). The economic effects of dividend taxation. In Altman, E. and Subrahmanyam, M. (eds.). Recent advances in corporate finance. Homewood, IL. Irwin Publishers, 227-284.

Selén, J. (2002). Taxable Income Responses to Tax Changes - A Panel Analysis of the 1990/91 Swedish Reform. Trade Union Institute for Economic Research, Working Paper No. 177.

Sinn, H. W. (1991). The vanishing Harberger triangle. Journal of Public Economics, 45, 271 300 .

Slemrod, J. B. (1995). Income creation or income shifting? Behavioral responses to the tax reform act of 1986. American Economic Review Papers and Proceedings, 85, 175-180.

Sørensen, P. B. (1994). From the global income tax to the dual income tax. Recent tax reforms in the Nordic countries. International Tax and Public Finance, 1, 57-79.

Sørensen, P. B. (1998) (eds.). Tax Policy in the Nordic Countries, London. Macmillan Press. 
Sørensen, P. B. (2005a). Neutral taxation and shareholder income. International Tax and Public Finance 12, 777-801.

Sørensen, P. B. (2005b). Dual income taxation. why and how? FinanzArchiv, 61, 559-586.

Thoresen, T. O. (2004). Reduced tax progressivity in Norway in the nineties. The effect from tax changes. International Tax and Public Finance, 11, 487-506.

Thoresen, T. O. \& Alstadsæter, A. (2008). Shifts in organizational form under a dual income tax system. CESifo Working Paper No. 2273. 


\section{Appendix}

Table A.1. Percentage of total: Corporations with positive proposed dividends and with excess proposed dividends (dividends $>$ After-tax profits), as well as corporations initiating and terminating dividend payments compared to previous year. Entire sample, $\mathrm{N}=\mathbf{7 6 4 4 4}$.

\begin{tabular}{rrrrr}
\hline Year & Div $>0$ & Div $>$ profits & Initiations & Terminations \\
\hline 1999 & 35.8 & 9.7 & & \\
2000 & 29.1 & 5.1 & 5.6 & 12.3 \\
2001 & 35.5 & 13.0 & 11.8 & 5.4 \\
2002 & 39.5 & 19.8 & 10.4 & 6.3 \\
2003 & 40.0 & 19.4 & 8.8 & 8.4 \\
2004 & 47.3 & 26.3 & 13.1 & 5.7 \\
2005 & 9.3 & 1.8 & 1.4 & 39.5 \\
2006 & 19.1 & 4.7 & 12.4 & 2.6 \\
\hline
\end{tabular}

Table A.2. Percentage of total: Corporations with positive proposed dividends and with excess proposed dividends (dividends $>$ After-tax profits), as well as corporations initiating and terminating dividend payments compared to previous year. Closely held corporations, $\mathrm{N}=\mathbf{3 8 5 8 4}$.

\begin{tabular}{lrrrr}
\hline Year & Div $>0$ & Div $>$ profits & Initiations & Terminations \\
\hline 1999 & 41.6 & 12.1 & & \\
2000 & 33.8 & 6.1 & 6.6 & 14.6 \\
2001 & 41.8 & 16.1 & 14.1 & 6.1 \\
2002 & 46.6 & 24.3 & 12.2 & 7.4 \\
2003 & 23.5 & 10.1 & 9.8 \\
2004 & 46.9 & 31.3 & 14.8 & 6.7 \\
2005 & 55.0 & 0.5 & 0.3 & 52.1 \\
2006 & 3.2 & 3.8 & 12.9 & 1.1 \\
\hline
\end{tabular}

Table A.3 Dividend-paying firms by percentage change in dividends. Percent

All non-listed firms

\begin{tabular}{ccccc} 
Year & Number of firms & $<0$ & $0-20$ percent & $>20$ percent \\
\hline 2000 & 18005 & 45.8 & 24.6 & 29.6 \\
2001 & 18123 & 25.3 & 22.7 & 52.0 \\
2002 & 22290 & 33.8 & 17 & 49.2 \\
2003 & 23833 & 48.1 & 15.9 & 36.0 \\
2004 & 26146 & 39.4 & 12.7 & 47.9 \\
2005 & 6001 & 59.7 & 15 & 25.3 \\
2006 & 5111 & 31.6 & 23 & 45.4 \\
\hline
\end{tabular}

Closely held firms

\begin{tabular}{rrrrr} 
Year & Number of firms & $<0$ & $0-20$ percent & $>20$ percent \\
2000 & 10506 & 48.7 & 22.8 & 28.5 \\
2001 & 10693 & 25.5 & 21.4 & 53.1 \\
2002 & 13529 & 34.6 & 16.3 & 49.1 \\
2003 & 14178 & 49.6 & 14.9 & 35.5 \\
2004 & 15491 & 41.2 & 12.2 & 46.6 \\
2005 & 1121 & 66.9 & 14.4 & 18.7 \\
\hline
\end{tabular}


Table A.4 Results of probit analysis. All corporations,

Number of observations $=589991$.

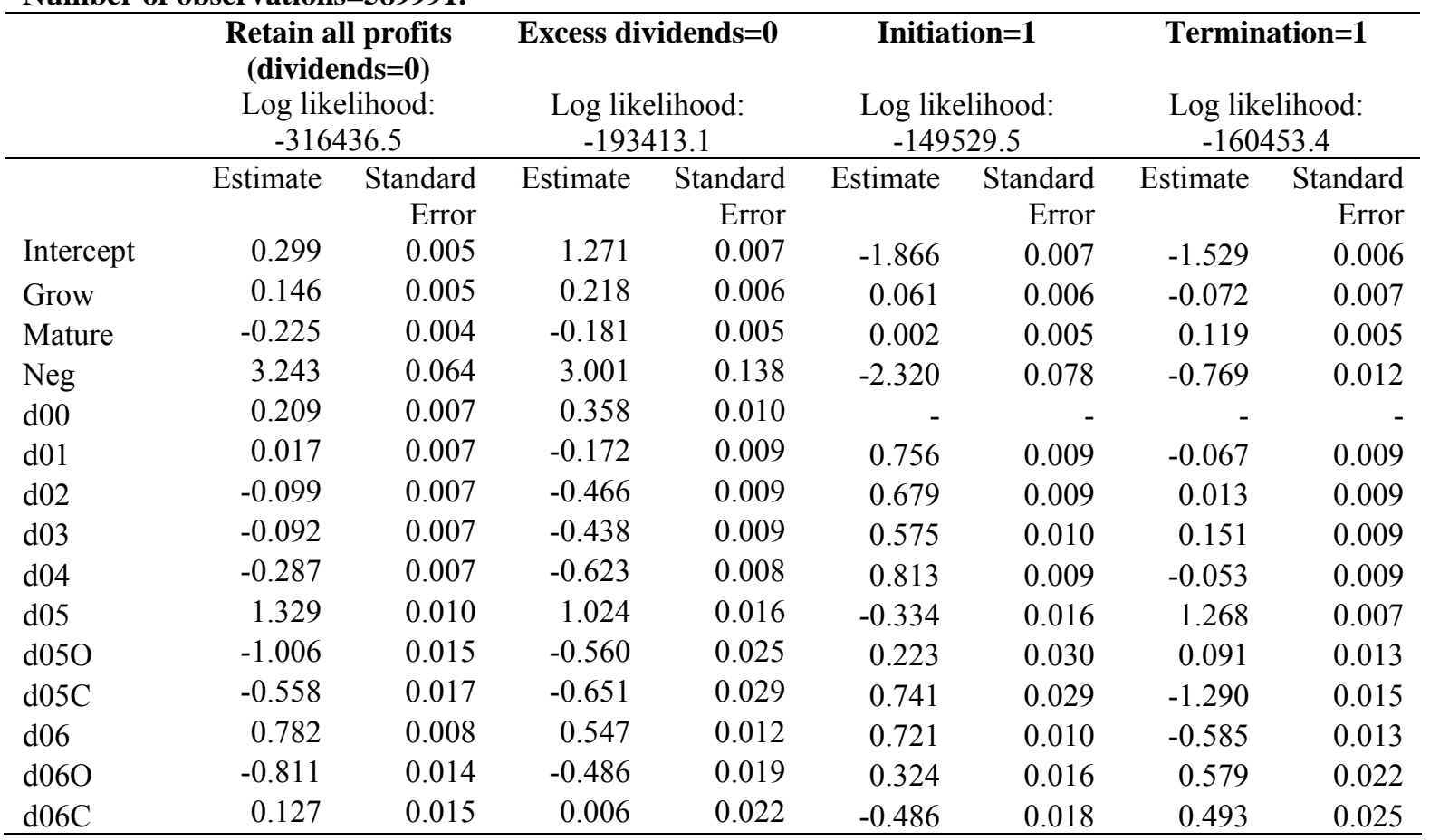

Table A.5. Difference-in-differences of debt ratios by dividends $>0 /=0$

All firms with book value $>500,000$ NOK

\begin{tabular}{lll}
\hline Book value & Dividend decision & Change in debt ratio \\
\hline Low-median & Div $=0$ & -0.29 \\
$\mathrm{~N}=31664$ & Div $>0$ & 0.05 \\
& Diff & $-0.34(* * *)$ \\
Median-9th decile & Div $=0$ & -0.12 \\
$\mathrm{~N}=67055$ & Div $>0$ & 0.05 \\
& Diff & $-0.18(* * *)$ \\
& & \\
Upper decile & Div $=0$ & -0.04 \\
$\mathrm{~N}=16857$ & Div $>0$ & 0.05 \\
& Diff & $-0.09(* * *)$ \\
\hline
\end{tabular}

$(* * *)$ means significant at 1 percent level, regardless equal or unequal variances

Table A.6 Difference-in-differences of debt ratios by dividends $>0$ /=0

Closely held firms with book value $>500,000$ NOK

\begin{tabular}{lll}
\hline Book value & Dividend decision & Change in debt ratio \\
\hline Low-median & Div $=0$ & -0.32 \\
$\mathrm{~N}=31434$ & Div $>0 \quad$ Diff & 0.01 \\
& & $-0.33(* * *)$ \\
Median-9th decile & Div $=0$ & -0.27 \\
$\mathrm{~N}=46853$ & Div $>0$ & -0.01 \\
& Diff & $-0.26(* * *)$ \\
Upper decile & Div $=0$ & -0.09 \\
$\mathrm{~N}=12283$ & Div $>0$ & -0.01 \\
& Diff & $-0.08(* * *)$ \\
\hline
\end{tabular}

$(* * *)$ means significant at 1 percent level, regardless equal or unequal variances 
Table A.7 OLS All corporations, Lower 90 percent Number of observations $=481600$

\section{Change in debt}

Intercept
d01
d02
d03
d04
d05
d06
Change

in assets ${ }^{2}$

$\mathrm{d} 01 \times \Delta \mathrm{A}$

$\mathrm{d} 02 \times \Delta \mathrm{A}$

$\mathrm{d} 03 \times \Delta \mathrm{A}$

d04 x $\Delta \mathrm{A}$

$\mathrm{d} 05 \times \Delta \mathrm{A}$

$\mathrm{d} 06 \mathrm{x} \Delta \mathrm{A}$

Dividends $>0{ }^{b}$

Dividends $>$ profits ${ }^{b}$
(1)

(2)

$22.6^{* *} \quad-9.1$

$27.3^{* *}$

$122.0^{*}$

$31.3^{* *}$

$181.3^{*}$

$-325.8^{*}$

$-183.1^{*}$

$0.34^{*}$

$-0.08^{*}$

$0.22^{*}$

$0.25^{*}$

$0.19^{*}$

$0.04^{*}$
$0.56^{*}$
Change in external equity
Change in internal equity

\begin{tabular}{|c|c|c|c|c|c|c|}
\hline idends & - & 473.6 & - & 94.2 & - & $-551 .($ \\
\hline $\mathrm{R}^{2}$ & 0.65 & 0.66 & 0.29 & 0.29 & 0.18 & 0.19 \\
\hline $\begin{array}{l}{ }^{\mathrm{a}} \text { Change in assets }=\mathrm{DA} \\
{ }^{\mathrm{b}} \text { Dummy variable }\end{array}$ & & & $\begin{array}{l}{ }^{*} \mathrm{~S} \\
{ }^{* *} \mathrm{~S} \\
\mathrm{*}\end{array}$ & $\begin{array}{l}\text { at } 1 \text { perc } \\
\text { at } 5 \text { perc } \\
\text { th } 10 \text { pe }\end{array}$ & & \\
\hline
\end{tabular}

Table A.8 OLS All corporations, Upper 10 percent by book value Number of observations $=53508$

\section{Change in debt}

(1)

\begin{tabular}{|c|c|c|c|c|c|c|}
\hline Intercept & $-5719.9^{* * *}$ & $-6933.0^{* *}$ & 2268.7 & 3442.3 & 3075.4 & 3251.7 \\
\hline $\mathrm{d} 01$ & $8240.0^{* * *}$ & 6913.1 & -4390.3 & -4159.3 & -3235.0 & -2367.7 \\
\hline $\mathrm{d} 02$ & 3762.0 & 1325.0 & -685.2 & -416.0 & -4379.3 & -2687.0 \\
\hline $\mathrm{d} 03$ & -1845.0 & -4533.3 & 3396.6 & 3707.7 & -2448.5 & -590.8 \\
\hline d04 & $18252.0^{*}$ & $14194.0^{*}$ & 4016.0 & 4523.8 & $-8993.9^{*}$ & $-6214.1^{* *}$ \\
\hline $\mathrm{d} 05$ & 3121.1 & 3500.9 & $-5750.3^{* *}$ & $-6188.4^{* *}$ & 3004.9 & 2995.0 \\
\hline $\mathrm{d} 06$ & -201.3 & -445.6 & -4444.9 & -4473.8 & 5023.0 & 5228.7 \\
\hline Change in assets ${ }^{a}$ & $0.86^{*}$ & $0.86^{*}$ & 0.0 & 0.0 & $0.07^{*}$ & $0.07^{*}$ \\
\hline $\mathrm{d} 01 \times \Delta \mathrm{A}$ & $-0.34^{*}$ & $-0.34^{*}$ & $0.33^{*}$ & $0.33^{*}$ & -0.01 & -0.01 \\
\hline $\mathrm{d} 02 \times \Delta \mathrm{A}$ & $-0.10^{*}$ & $-0.10^{*}$ & $0.06^{*}$ & $0.06^{*}$ & $0.08^{*}$ & $0.08^{*}$ \\
\hline $\mathrm{d} 03 \times \Delta \mathrm{A}$ & $-0.10^{*}$ & $-0.10^{*}$ & $0.06^{*}$ & $0.06^{*}$ & 0.0 & 0.0 \\
\hline $\mathrm{d} 04 \times \Delta \mathrm{A}$ & $0.23^{*}$ & $0.23^{*}$ & $0.10^{*}$ & $0.10^{*}$ & $0.14^{*}$ & $0.14^{*}$ \\
\hline $\mathrm{d} 05 \times \Delta \mathrm{A}$ & $-0.37^{*}$ & $-0.37^{*}$ & $0.48^{*}$ & $0.48^{*}$ & $-0.04^{*}$ & $-0.04^{*}$ \\
\hline $\mathrm{d} 06 \times \Delta \mathrm{A}$ & $-0.09^{*}$ & $-0.09^{*}$ & $-0.04^{*}$ & $-0.04^{*}$ & $0.2^{*}$ & $0.2^{*}$ \\
\hline Dividends $>0^{b}$ & - & 1205.5 & - & $-4458.5^{* *}$ & - & 1934.2 \\
\hline Dividends $>$ profits ${ }^{b}$ & - & $22881.0^{*}$ & - & 1187.6 & - & $-18270^{*}$ \\
\hline $\mathrm{R}^{2}$ & 0.53 & 0.53 & 0.20 & 0.20 & 0.06 & 0.06 \\
\hline $\begin{array}{l}{ }^{\mathrm{a}} \text { Change in assets }=\mathrm{DA} \\
{ }^{\mathrm{b}} \text { Dummy variable }\end{array}$ & & & $\begin{array}{l}{ }^{*} \mathrm{Si} \\
{ }^{* *} \mathrm{Si} \\
{ }^{* * *} \mathrm{Si}\end{array}$ & $\begin{array}{l}\text { at } 1 \text { perc } \\
\text { at } 5 \text { perc } \\
\text { at } 10 \text { per }\end{array}$ & & \\
\hline
\end{tabular}

Change in external equity
(4)

$27.3^{*}$

$-14.8$

13.0

$47.9^{*}$

$38.6^{*}$

$64.4^{*}$

$-56.3^{*}$

$0.11^{*}$

$-0.01^{*}$

$0.14^{*}$

$-0.07^{*}$

$0.03^{*}$

$0.04^{*}$

$0.13^{*}$

0.13
$-75.9^{*}$ (5)

$-10.3$

$-32.7^{* *}$

$-158.6^{*}$

$-101.7^{*}$

$-163.9^{*}$

$226.5^{*}$

$209.1^{*}$

$0.27^{*}$

$-0.28^{*}$

$-0.01^{*}$

$-0.09^{*}$

$-0.19^{*}$

$-0.16^{*}$

$-0.10^{*}$
$-0.16$

$-0.10$

(6)

4.6

9.13

$-79.9$

-26.0
-52.9

217.0

211.4

0.27

$-0.28$

$-0.01$

$-0.01$

0.19

4.1

${ }^{* * *}$ Significant at 5 percent level. . 


\section{CESifo Working Paper Series}

for full list see www.cesifo-group.org/wp

(address: Poschingerstr. 5, 81679 Munich, Germany, office@cesifo.de)

2465 Claudia M. Buch, The Great Risk Shift? Income Volatility in an International Perspective, November 2008

2466 Walter H. Fisher and Ben J. Heijdra, Growth and the Ageing Joneses, November 2008

2467 Louis Eeckhoudt, Harris Schlesinger and Ilia Tsetlin, Apportioning of Risks via Stochastic Dominance, November 2008

2468 Elin Halvorsen and Thor O. Thoresen, Parents' Desire to Make Equal Inter Vivos Transfers, November 2008

2469 Anna Montén and Marcel Thum, Ageing Municipalities, Gerontocracy and Fiscal Competition, November 2008

2470 Volker Meier and Matthias Wrede, Reducing the Excess Burden of Subsidizing the Stork: Joint Taxation, Individual Taxation, and Family Splitting, November 2008

2471 Gunther Schnabl and Christina Ziegler, Exchange Rate Regime and Wage Determination in Central and Eastern Europe, November 2008

2472 Kjell Erik Lommerud and Odd Rune Straume, Employment Protection versus Flexicurity: On Technology Adoption in Unionised Firms, November 2008

2473 Lukas Menkhoff, High-Frequency Analysis of Foreign Exchange Interventions: What do we learn?, November 2008

2474 Steven Poelhekke and Frederick van der Ploeg, Growth, Foreign Direct Investment and Urban Concentrations: Unbundling Spatial Lags, November 2008

2475 Helge Berger and Volker Nitsch, Gotcha! A Profile of Smuggling in International Trade, November 2008

2476 Robert Dur and Joeri Sol, Social Interaction, Co-Worker Altruism, and Incentives, November 2008

2477 Gaëtan Nicodème, Corporate Income Tax and Economic Distortions, November 2008

2478 Martin Jacob, Rainer Niemann and Martin Weiss, The Rich Demystified - A Reply to Bach, Corneo, and Steiner (2008), November 2008

2479 Scott Alan Carson, Demographic, Residential, and Socioeconomic Effects on the Distribution of $19^{\text {th }}$ Century African-American Stature, November 2008

2480 Burkhard Heer and Andreas Irmen, Population, Pensions, and Endogenous Economic Growth, November 2008 
2481 Thomas Aronsson and Erkki Koskela, Optimal Redistributive Taxation and Provision of Public Input Goods in an Economy with Outsourcing and Unemployment, December 2008

2482 Stanley L. Winer, George Tridimas and Walter Hettich, Social Welfare and Coercion in Public Finance, December 2008

2483 Bruno S. Frey and Benno Torgler, Politicians: Be Killed or Survive, December 2008

2484 Thiess Buettner, Nadine Riedel and Marco Runkel, Strategic Consolidation under Formula Apportionment, December 2008

2485 Irani Arraiz, David M. Drukker, Harry H. Kelejian and Ingmar R. Prucha, A Spatial Cliff-Ord-type Model with Heteroskedastic Innovations: Small and Large Sample Results, December 2008

2486 Oliver Falck, Michael Fritsch and Stephan Heblich, The Apple doesn't Fall far from the Tree: Location of Start-Ups Relative to Incumbents, December 2008

2487 Cary Deck and Harris Schlesinger, Exploring Higher-Order Risk Effects, December 2008

2488 Michael Kaganovich and Volker Meier, Social Security Systems, Human Capital, and Growth in a Small Open Economy, December 2008

2489 Mikael Elinder, Henrik Jordahl and Panu Poutvaara, Selfish and Prospective: Theory and Evidence of Pocketbook Voting, December 2008

2490 Maarten Bosker and Harry Garretsen, Economic Geography and Economic Development in Sub-Saharan Africa, December 2008

2491 Urs Fischbacher and Simon Gächter, Social Preferences, Beliefs, and the Dynamics of Free Riding in Public Good Experiments, December 2008

2492 Michael Hoel, Bush Meets Hotelling: Effects of Improved Renewable Energy Technology on Greenhouse Gas Emissions, December 2008

2493 Christian Bruns and Oliver Himmler, It's the Media, Stupid - How Media Activity Shapes Public Spending, December 2008

2494 Andreas Knabe and Ronnie Schöb, Minimum Wages and their Alternatives: A Critical Assessment, December 2008

2495 Sascha O. Becker, Peter H. Egger, Maximilian von Ehrlich and Robert Fenge, Going NUTS: The Effect of EU Structural Funds on Regional Performance, December 2008

2496 Robert Dur, Gift Exchange in the Workplace: Money or Attention?, December 2008

2497 Scott Alan Carson, Nineteenth Century Black and White US Statures: The Primary Sources of Vitamin D and their Relationship with Height, December 2008 
2498 Thomas Crossley and Mario Jametti, Pension Benefit Insurance and Pension Plan Portfolio Choice, December 2008

2499 Sebastian Hauptmeier, Ferdinand Mittermaier and Johannes Rincke, Fiscal Competition over Taxes and Public Inputs: Theory and Evidence, December 2008

2500 Dirk Niepelt, Debt Maturity without Commitment, December 2008

2501 Andrew Clark, Andreas Knabe and Steffen Rätzel, Boon or Bane? Others' Unemployment, Well-being and Job Insecurity, December 2008

2502 Lukas Menkhoff, Rafael R. Rebitzky and Michael Schröder, Heterogeneity in Exchange Rate Expectations: Evidence on the Chartist-Fundamentalist Approach, December 2008

2503 Salvador Barrios, Harry Huizinga, Luc Laeven and Gaëtan Nicodème, International Taxation and Multinational Firm Location Decisions, December 2008

2504 Andreas Irmen, Cross-Country Income Differences and Technology Diffusion in a Competitive World, December 2008

2505 Wenan Fei, Claude Fluet and Harris Schlesinger, Uncertain Bequest Needs and LongTerm Insurance Contracts, December 2008

2506 Wido Geis, Silke Uebelmesser and Martin Werding, How do Migrants Choose their Destination Country? An Analysis of Institutional Determinants, December 2008

2507 Hiroyuki Kasahara and Katsumi Shimotsu, Sequential Estimation of Structural Models with a Fixed Point Constraint, December 2008

2508 Barbara Hofmann, Work Incentives? Ex Post Effects of Unemployment Insurance Sanctions - Evidence from West Germany, December 2008

2509 Louis Hotte and Stanley L. Winer, The Demands for Environmental Regulation and for Trade in the Presence of Private Mitigation, December 2008

2510 Konstantinos Angelopoulos, Jim Malley and Apostolis Philippopoulos, Welfare Implications of Public Education Spending Rules, December 2008

2511 Robert Orlowski and Regina T. Riphahn, The East German Wage Structure after Transition, December 2008

2512 Michel Beine, Frédéric Docquier and Maurice Schiff, International Migration, Transfers of Norms and Home Country Fertility, December 2008

2513 Dirk Schindler and Benjamin Weigert, Educational and Wage Risk: Social Insurance vs. Quality of Education, December 2008

2514 Bernd Hayo and Stefan Voigt, The Relevance of Judicial Procedure for Economic Growth, December 2008 
2515 Bruno S. Frey and Susanne Neckermann, Awards in Economics - Towards a New Field of Inquiry, January 2009

2516 Gregory Gilpin and Michael Kaganovich, The Quantity and Quality of Teachers: A Dynamic Trade-off, January 2009

2517 Sascha O. Becker, Peter H. Egger and Valeria Merlo, How Low Business Tax Rates Attract Multinational Headquarters: Municipality-Level Evidence from Germany, January 2009

2518 Geir H. Bjønnes, Steinar Holden, Dagfinn Rime and Haakon O.Aa. Solheim, ,Large' vs. ,Small' Players: A Closer Look at the Dynamics of Speculative Attacks, January 2009

2519 Jesus Crespo Cuaresma, Gernot Doppelhofer and Martin Feldkircher, The Determinants of Economic Growth in European Regions, January 2009

2520 Salvador Valdés-Prieto, The 2008 Chilean Reform to First-Pillar Pensions, January 2009

2521 Geir B. Asheim and Tapan Mitra, Sustainability and Discounted Utilitarianism in Models of Economic Growth, January 2009

2522 Etienne Farvaque and Gaël Lagadec, Electoral Control when Policies are for Sale, January 2009

2523 Nicholas Barr and Peter Diamond, Reforming Pensions, January 2009

2524 Eric A. Hanushek and Ludger Woessmann, Do Better Schools Lead to More Growth? Cognitive Skills, Economic Outcomes, and Causation, January 2009

2525 Richard Arnott and Eren Inci, The Stability of Downtown Parking and Traffic Congestion, January 2009

2526 John Whalley, Jun Yu and Shunming Zhang, Trade Retaliation in a Monetary-Trade Model, January 2009

2527 Mathias Hoffmann and Thomas Nitschka, Securitization of Mortgage Debt, Asset Prices and International Risk Sharing, January 2009

2528 Steven Brakman and Harry Garretsen, Trade and Geography: Paul Krugman and the 2008 Nobel Prize in Economics, January 2009

2529 Bas Jacobs, Dirk Schindler and Hongyan Yang, Optimal Taxation of Risky Human Capital, January 2009

2530 Annette Alstadsæter and Erik Fjærli, Neutral Taxation of Shareholder Income? Corporate Responses to an Announced Dividend Tax, January 2009 